\title{
Use of 3D laser microscopy to determine plant pollen
}

Anna-Luisa Weber, Klaus Weber, Sebastian Pretot, Marco Sillipo, Leonardo Lombardi, Nils Warfving

AnaPath Services GmbH

Hammerstrasse 49

4410 Liestal, Switzerland

\begin{abstract}
Pollen analysis as a part of palynology deals with the morphological determination of pollen and spores. Different technologies with different resolutions varying from simple light microscopy to highly elaborate electron microscopy are used for the examination, depending on the area of application (e.g. sedimentology, melissopalynology, forensic palynology, etc.). To answer the question of whether laser scanning microscopy (LSM) can replace scanning electron microscopy (SEM) for the determination of pollen species, 168 species were examined using LSM.

It was concluded that LSM is both efficient and easy to handle. After preparing the fresh pollen, a 3D laser scan takes 5-10 minutes and unlike using SEM, the pollen does not have to be sputtered or processed. The 3D scans can be measured quickly and easily with the integrated software and there were no observable artifacts. At magnifications up to $8545 \mathrm{x}$, the image quality is comparable to that of a sputtered SEM sample whereas at higher magnifications, the SEM method is superior. Overall, pollen display by LSM is much less time consuming and more cost effective than with the SEM method.
\end{abstract}

\section{Key Words}

pollen, pollen classes, determination, 3D, laser scanning microscopy

\section{Introduction}

Modern processes and techniques have become an integral part of biological science and are constantly evolving. This is particularly true for microscopy wherein techniques have been refined and perfected thus allowing us to penetrate ever smaller worlds.

Pollen consists of pollen grains and is formed only in the stamens of seed plants. Pollen has a wall, the sporoderm, which is so robust that even prehistoric fauna can still be analyzed after hundreds of millions of years based on pollen classification [1]. Palynology uses the morphological characterization of pollen and thus the taxonomic assignment of plants $[2,3]$. In the strictest sense, palynology deals with the analysis of fossil and subfossil pollen and spores from paleontological and quaternary deposits (especially peat, and lake or river sediments) [4, $5,6]$. However, pollen analysis can also be used to find answers in different fields, including questions in criminology (forensic palynology) [7, 8], the food industry (honey; melissopalynology) [9, 10], and medicine (air; aeropalynology) [11]. Furthermore, palynology is of great economic importance in coal and oil exploration [5].

Recent pollen can be examined very easily under a light microscope without major precautions. Pollen can be examined in detail morphologically. Under classic conditions, the pollen is subjected to acetolysis with sulfuric acid and subsequent bleaching with $\mathrm{KClO}$ (potassium 
hypochlorite) [2]. Acid-free preparation methods are also discussed [12]. These methods make it possible to visualize the inner structures of pollen grains.

For melissopalynology, pollen must first be enriched, since little pollen is found just in the honey. To do this, water is added to honey, which is then centrifuged, and the samples are examined directly under the microscope. Guide pollen (the most important pollen type) and the accompanying pollen are determined [13].

Very precise pollen surface details can be obtained using the scanning electron microscope [14, 15, 16, 17]. An excellent summary of pollen morphology by SEM was published by Halbritter et al. (2019) [18]. This technology serves, on the one hand, to better classify pollen taxa [14], purity tests in honey [19] and, on the other, to quantify and differentiate pollen types in pollen count [15]. However, this method is very time-consuming and labor and cost intensive [16].

Both light and scanning electron microscopy have advantages and disadvantages. Light microscope examinations give little idea of the spatial shape of the pollen and provide few details about complicated surface structures, however, they do reveal the inner structures of pollen grains. Scanning electron microscope examinations only allow the examination of the surface structures but offer the possibility of taking high-resolution images of these structures.

LSM is a technique which uses a focused laser and confocal technology for scanning an object. It allows surfaces to be studied and imaged at high resolution, with up to 17280x total magnification. The technology was developed mainly for material sciences and quality control but has been previously described as a useful technique for the evaluation of sperm cells [20]. The present paper deals with the application of LSM for the evaluation of plant pollen using the Olympus LEXT OLS4000 3D confocal laser scanning microscope.

\section{Material and Methods}

\section{Inventory of flowering plants in the collecting area}

All the pollen of the species examined for the present work comes from the vicinity of a little creek called Mühlebach and its inflows in the municipality of Oberbuchsiten, Switzerland [21]. Pollen were collected with a small amount of antheres by walking the area once every two weeks between January and July 2019.

\section{$\underline{\text { Pollen collection }}$}

The plant species were determined on site. Each plant was photographed for inventory. Stamens from one flower from each newly found flowering plant were transferred to labeled 1.5-ml Eppendorf tubes for analysis in the laboratory. At the AnaPath Services GmbH laboratory (Oberbuchsiten, Switzerland), each stamen was removed from its tube and the pollen was stripped or shaken out onto a slide. The slides were labeled and transferred to the laboratory of AnaPath Services GmbH (Liestal, Switzerland) where laser scanning microscopy (LSM) was performed.

\section{LEXT OLS4000 3D Confocal Laser Scanning Microscope}

Images were acquired at AnaPath Services GmbH (Liestal, Switzerland), with a LEXT OLS4000 3D Confocal Laser Scanning Microscope. The LEXT OLS4000 employs a dual confocal system using a $405 \mathrm{~nm}$ optical laser. Total magnification ranges from 108x to 17280x. 
The technology applied on biological samples was published by Weber et al. (2014). In contrast to previous alternative published methods, the pollen samples were imaged without further processing, treatment or fixation. Imaging was performed at magnifications of 1179x or 2350x. Color-setting was occasionally applied to improve the visibility of details (Figure 1). For visualization of finer details, final enlargements up to $8545 \mathrm{x}$ were obtained (Figure 2). Individual pollen types were measured using the integrated LEXT OLS4000 software (Figures 21-23). Drawings made by Anna-Luisa Weber after Beug (2004) [2].

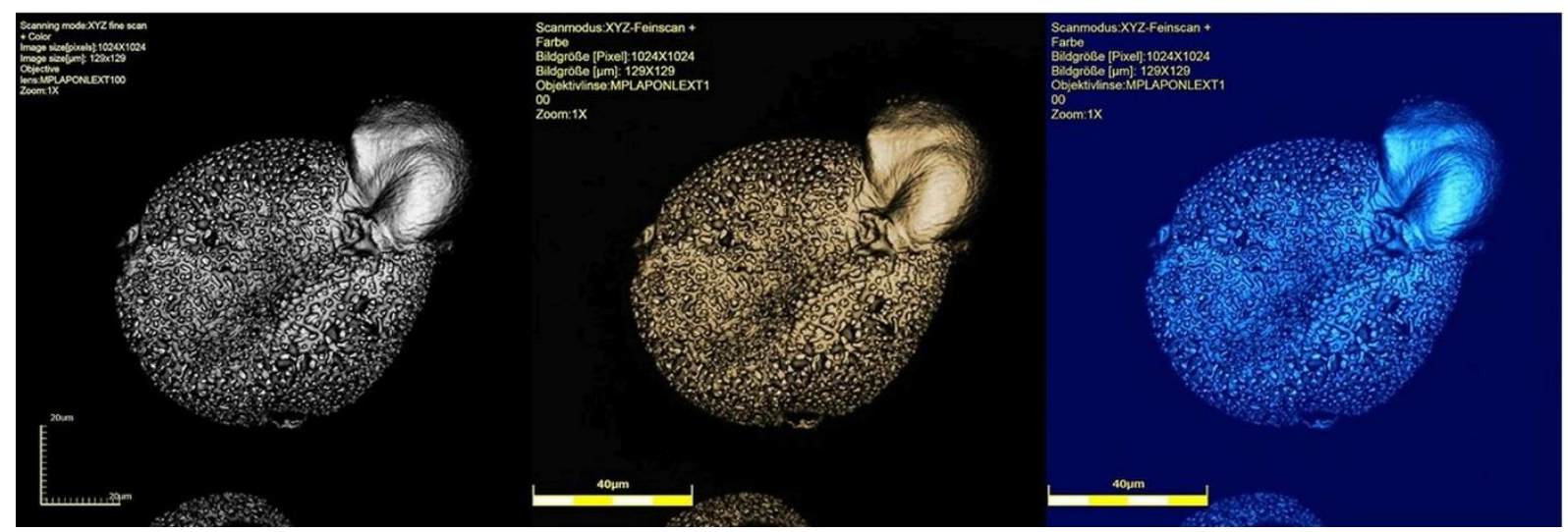

Figure 1: Geranium robertianum. Pollen grain with germinating pollen tube. Coloring makes it easier to highlight different details visually. LSM, Original magnification x 213

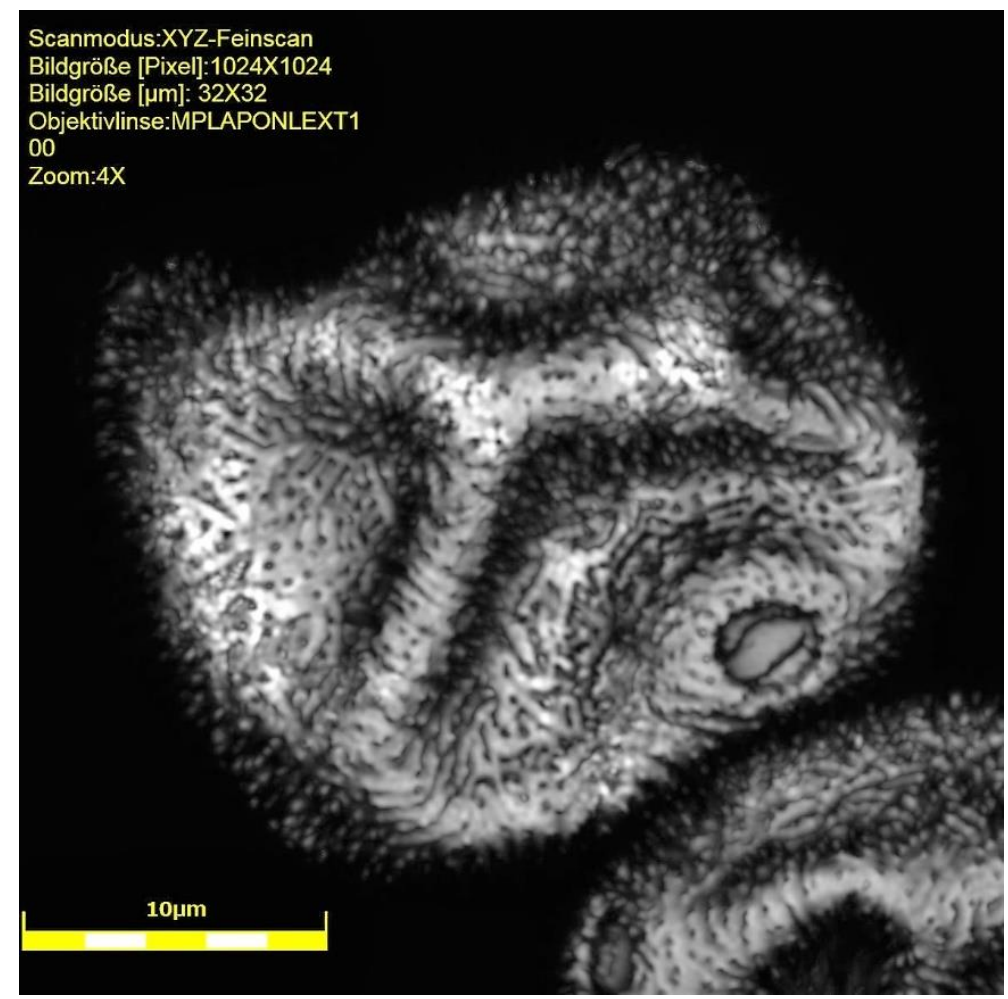

Figure 2: Example of maximal useful magnification. Betula pendula. LSM, original enlargement $x 8545$.

\section{$\underline{\text { Scanning electron microscopy (SEM) }}$}

Samples from Antirrhinum majus pollen were sputtered with platinum and scanned with a scanning electron microscope (Zeiss DSM 982) at the Institute of Veterinary Anatomy at the University of Bern, Switzerland (Prof. Dr. med. vet. Michael Stoffel). Furthermore, non- 
sputtered pollen from Erigeron annuиs was examined by scanning electron microscope (Phenom XL Desktop SEM / ThermoFisherScientific) for comparison purposes at AnaPath Services GmbH (Liestal, Switzerland) (Dr. Marco Silipo).

\section{Results}

$\underline{\text { Systematics and assignment of the evaluated plants to pollen classes }}$

Pollen from 168 species from 47 families and 129 genera were collected (Table 2). From the 33 main pollen classes according to Beug (2004) [2], the pollen of the collected species could be assigned to 16 classes, including Polyadeae (Figure 3), Tetradeae (Figure 4), Vesiculatae (Figure 5), Fenestratae (Figure 6), Monoporatae (Figure 7), Monocolpatae (Figure 8), Syncolpatae (Figure 9), Triporatae (Figure 10), Tricolpatae (Figures 11, 14), Tricolporatae (Figures 12, 14), Tricolporoidatae (Figures 13, 14), Stephanocolpatae (Figure 15), Stephanoporatae (Figure 16), Stephanocolporatae (Figure 17), Heterocolpatae (Figure 18), Periporatae (Figure 19) and Pericolpatae (Figure 20). No examples were found for Inaperturatae, Polyplicatae, Diporatae, Dicolpatae, Dicolporatae or Pericolporatae.

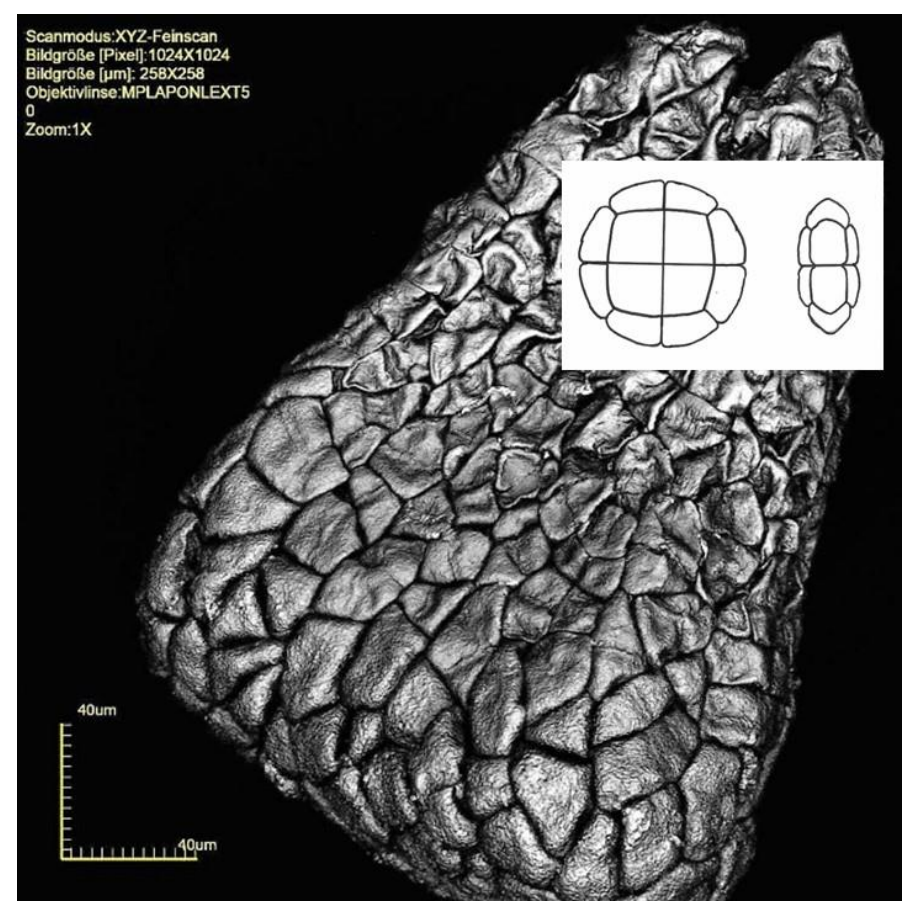

Figure 3: Polyadeae. Many pollen grains united. A pollinium, i.e. a package of pollen typical for Orchidaceae and some Apocyanaceae, is shown here. Sample species: Ophrys apifera. Original magnification x1072. 


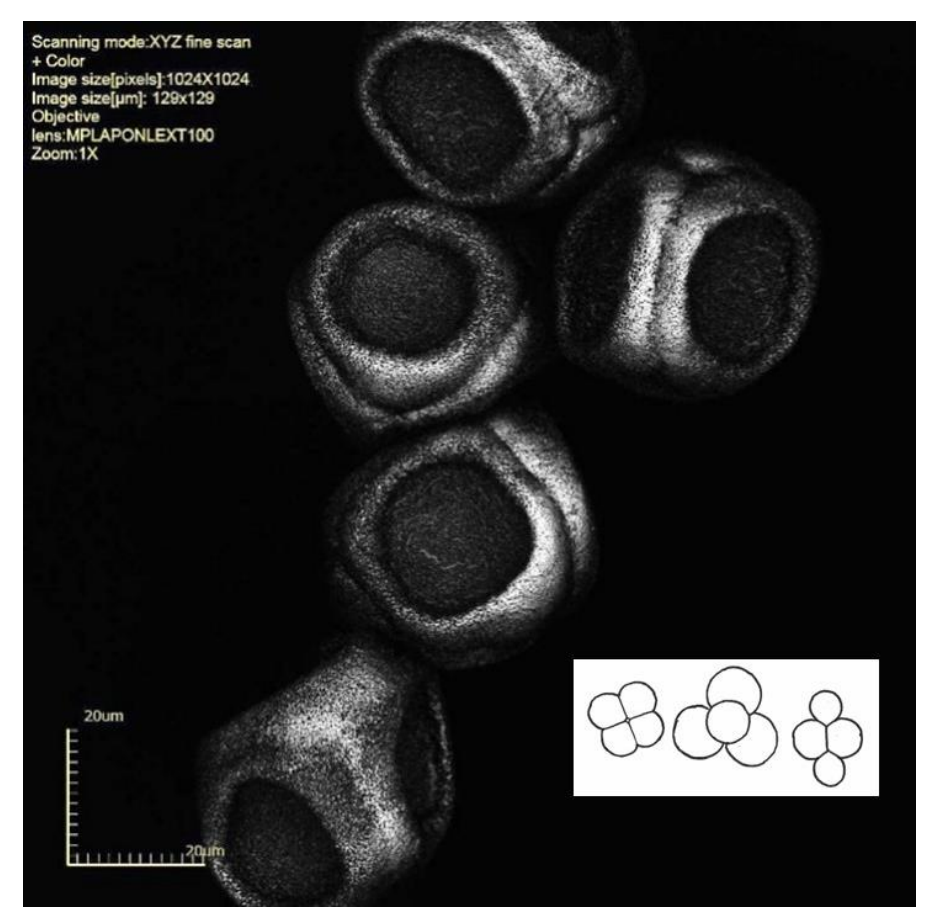

Figure 4: Tetradeae. Four united pollen grains. Sample species: Luzula pilosa. Type: Juncus. Original magnification $\mathrm{x} 2136$.

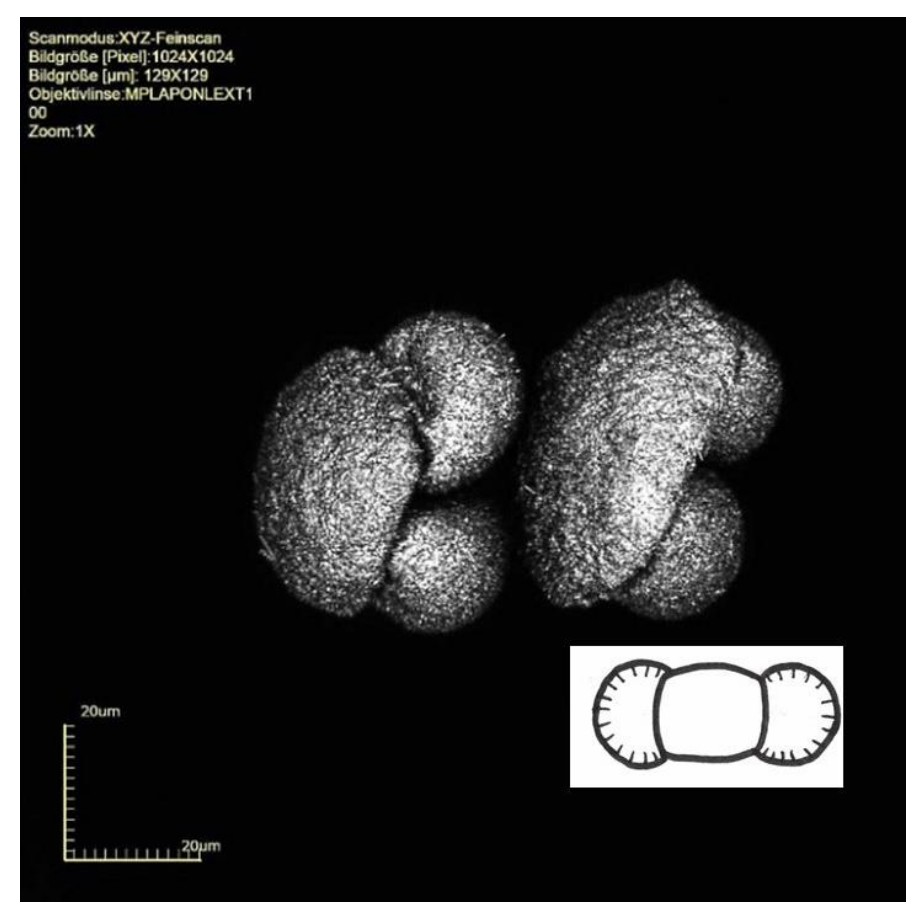

Figure 5: Vesiculatae. Pollen grains with two separate or one ring-shaped airbag. Sample species: Pinus sylvestris. Type: Pinus sylvestris-Type. Original magnification x 2136 . 


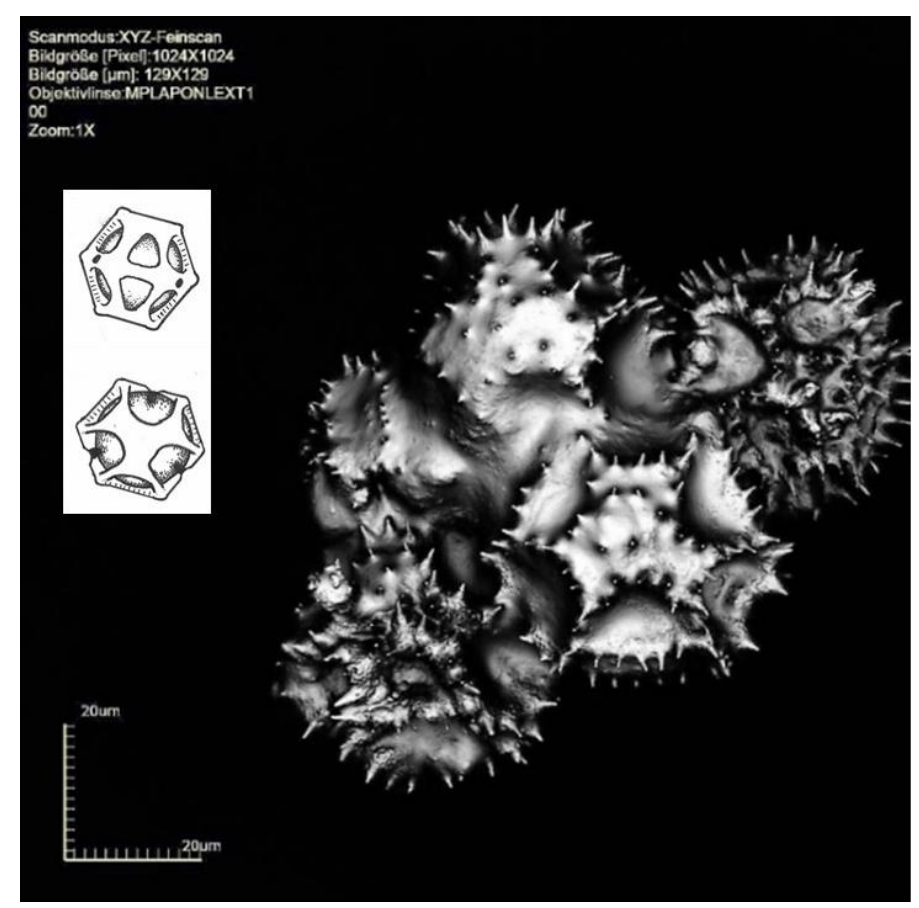

Figure 6: Fenestratae. Pollen grains with lacunae (round or angular areas) which are delimited by ribs and in which the ectexine are missing. Sample species: Tragopogon pratensis. Type: Tragopogon. Original magnification $\mathrm{x} 2136$.

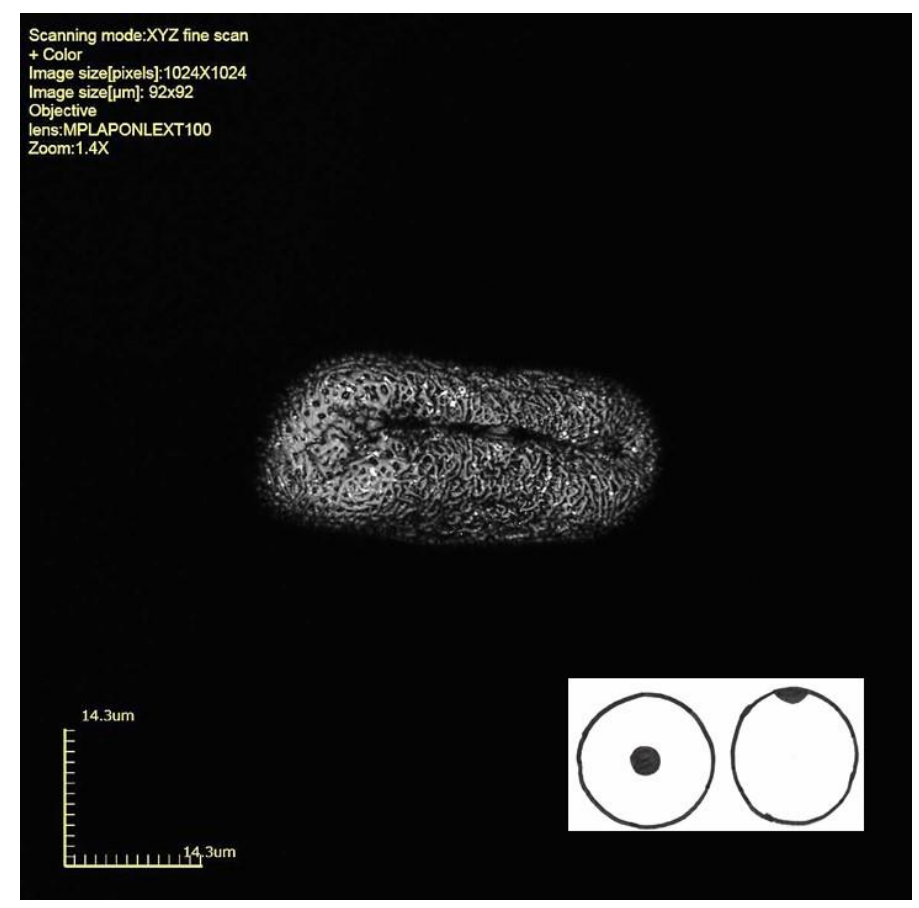

Figure 7: Monoporatae. Pollen grains with only one pore. Sample species: Phleum pratense. Type: Poaceae. Original magnification x2991. 


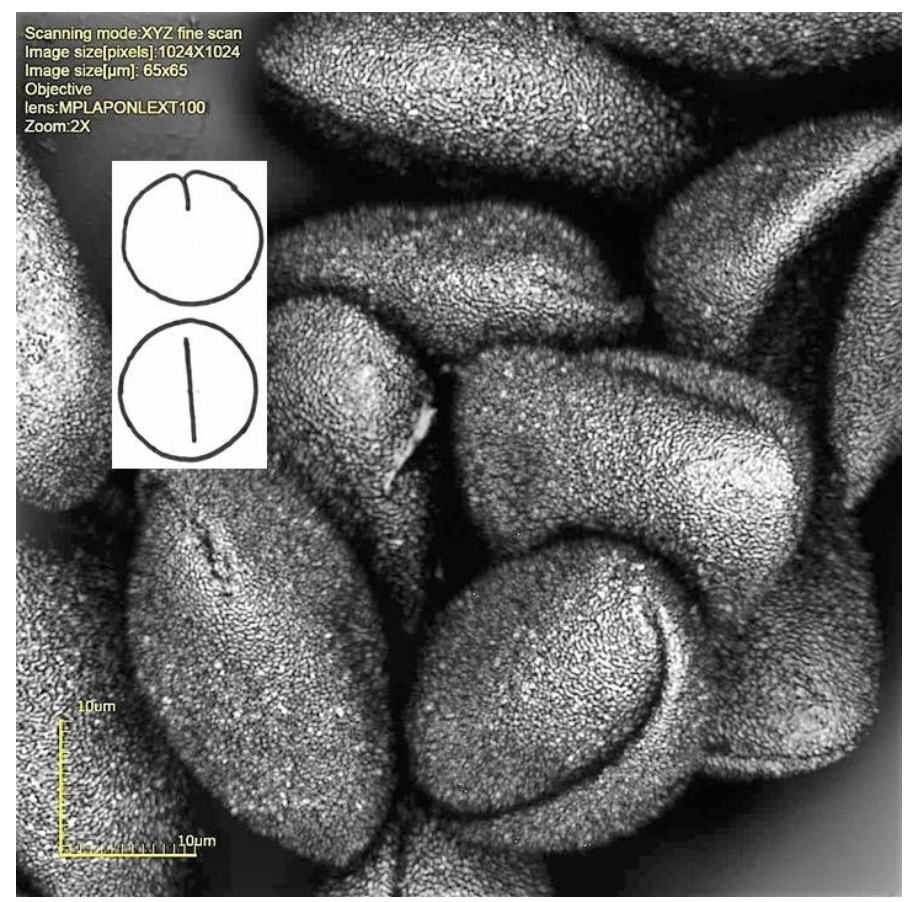

Figure 8: Monocolpatae. Pollen grains with only one colpus. Sample species: Leucojum vernum. Type: Leucojum-Type. Original magnification x4273.

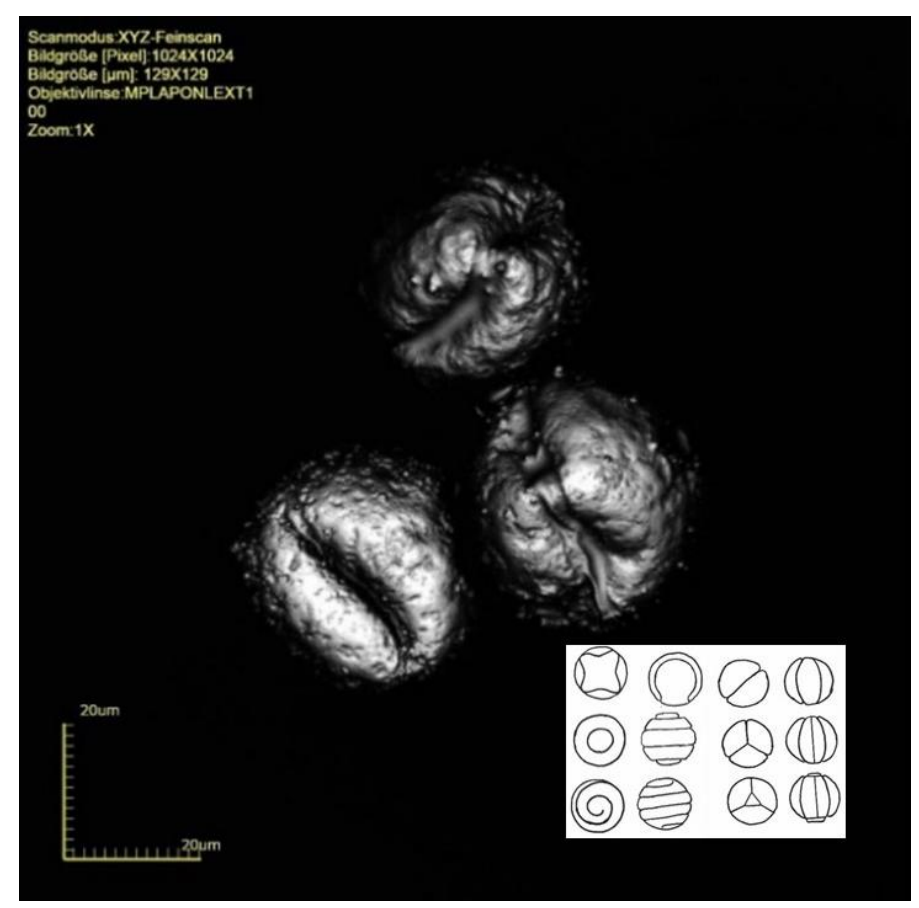

Figure 9: Syncolpatae. Ring-shaped or helical colpus or two to three polar connected colpae, or colpae which divide the surface of the pollen grain into square areas and are connected to one another. Sample species: Berberis vulgaris. Type: Berberis vulgaris. Original magnification $\mathrm{x} 2136$. 


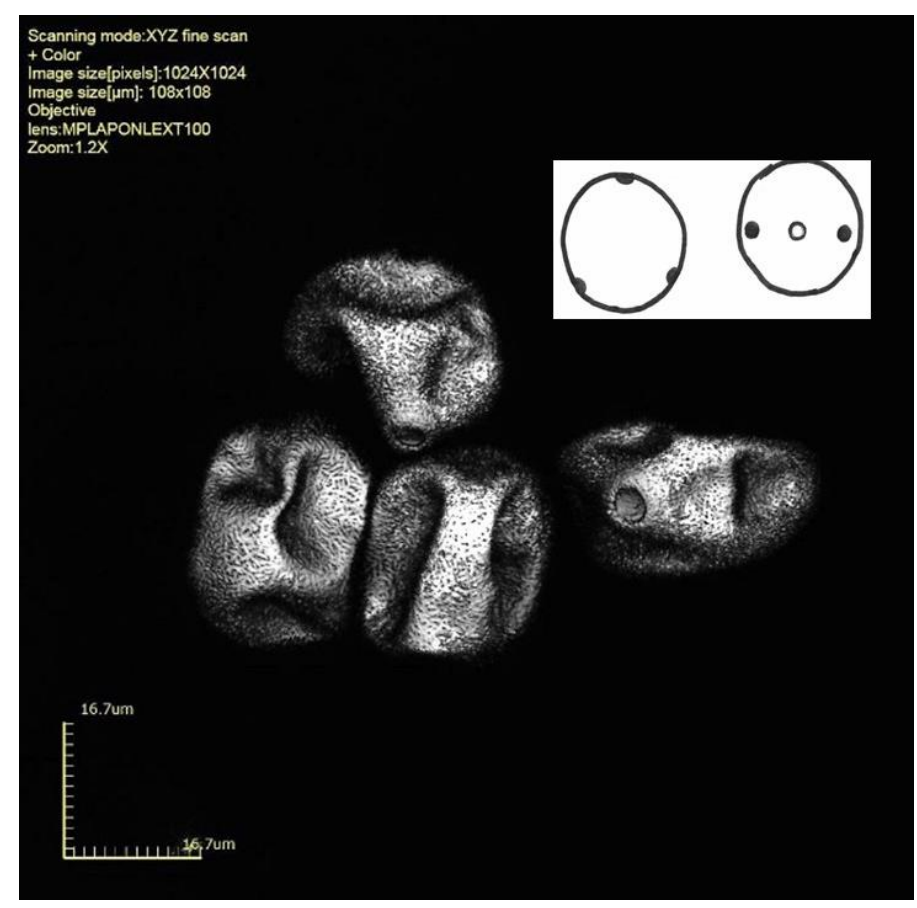

Figure 10: Triporatae. Pollen grains with three pores. Sample species: Betula pendula. Type: Betula. Original magnification x2564.

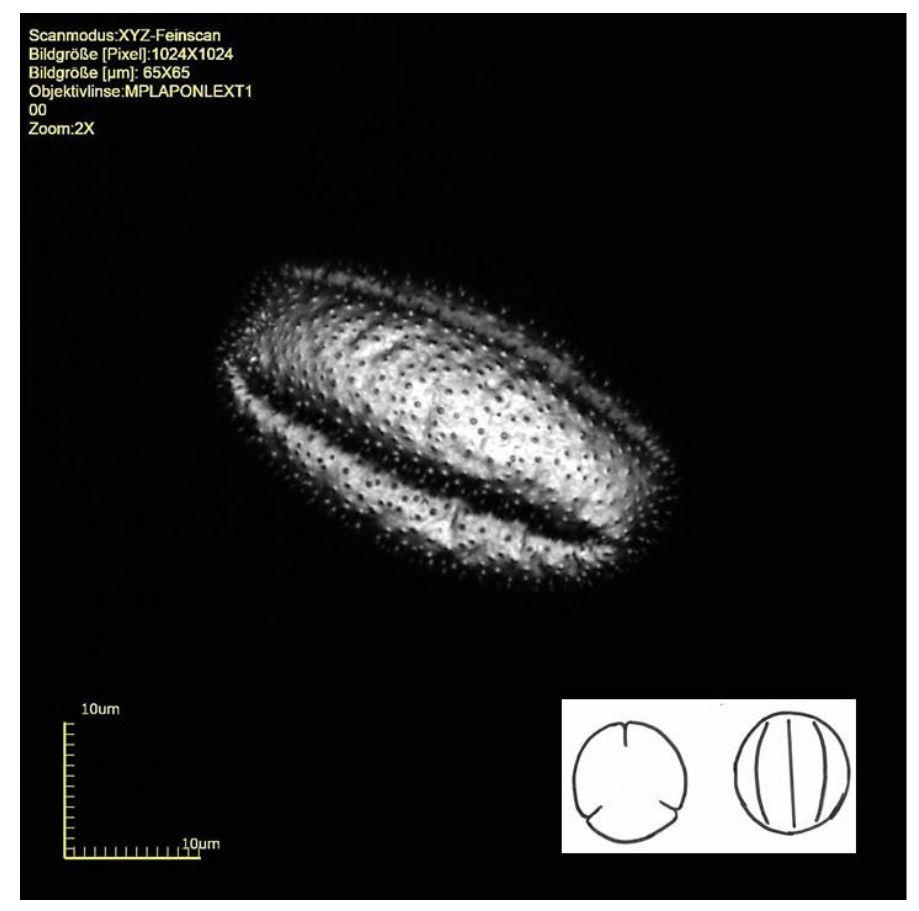

Figure 11: Tricolpatae. Pollen grains with three colpae. Sample species: Anemone ranunculoides. Type: Ranunculus acris-Type. Original magnification x4273. 


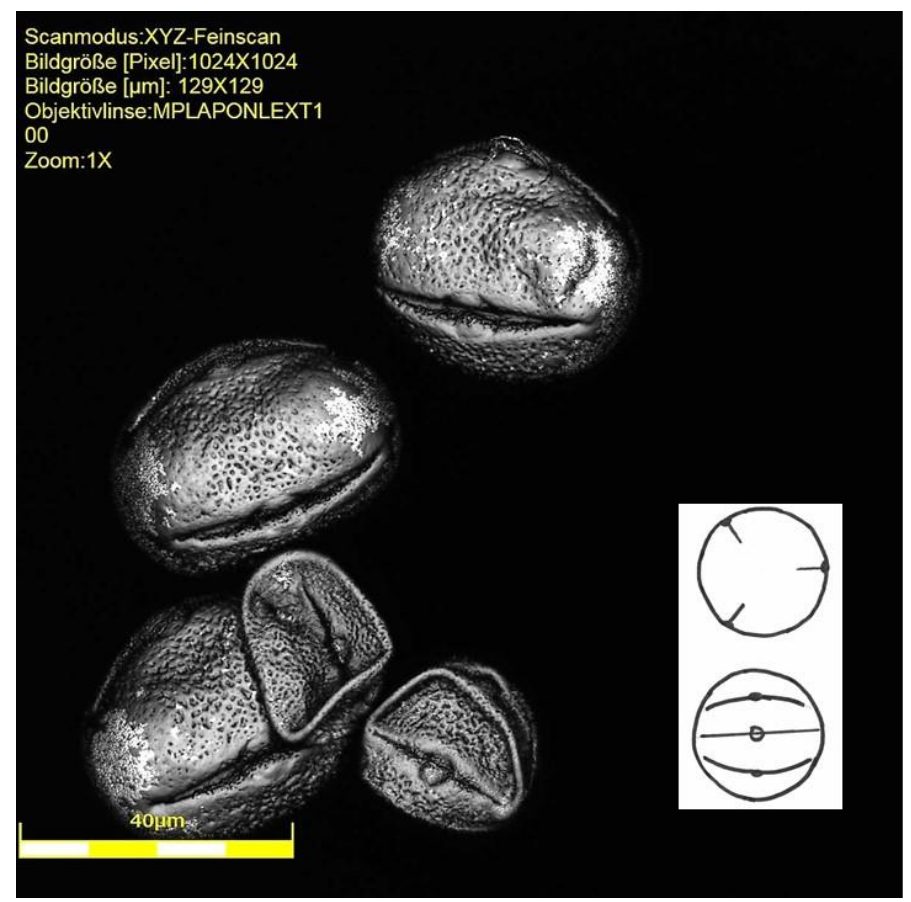

Figure 12: Tricolporatae. Pollen grains with three colpae and additionally with three pores oriented in the middle. Sample species: Lathyrus vernus. Type: Lathyrus-Type. Original magnification $\mathrm{x} 2136$.

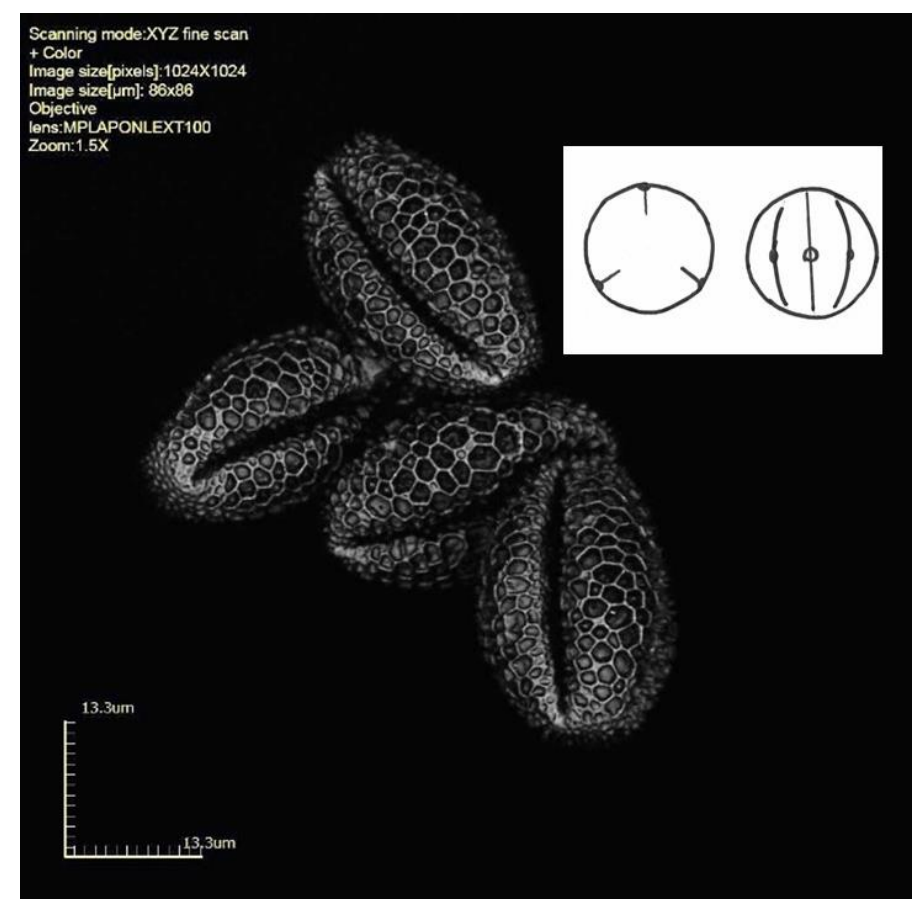

Figure 13: Tricolporoidatae. Structures like Tricolporatae but with pore-like structures instead of pores. Sample species: Sambucus nigra. Type: Sambucus-nigra-Type. Original magnification x3204. 


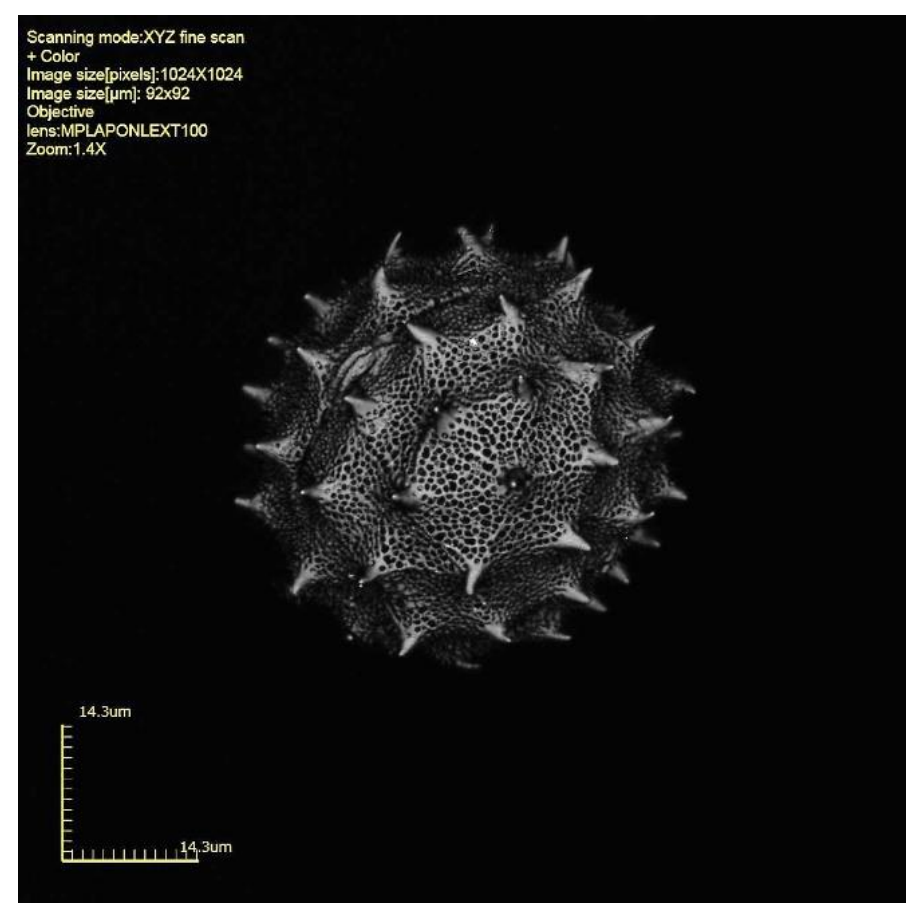

Figure 14: Classified as Tricolpatae, Tricolporoidatae, Tricolporatae after Beug (2004). Sample species: Cirsium oleraceum. Type: Cirsium. Original magnification x2991.

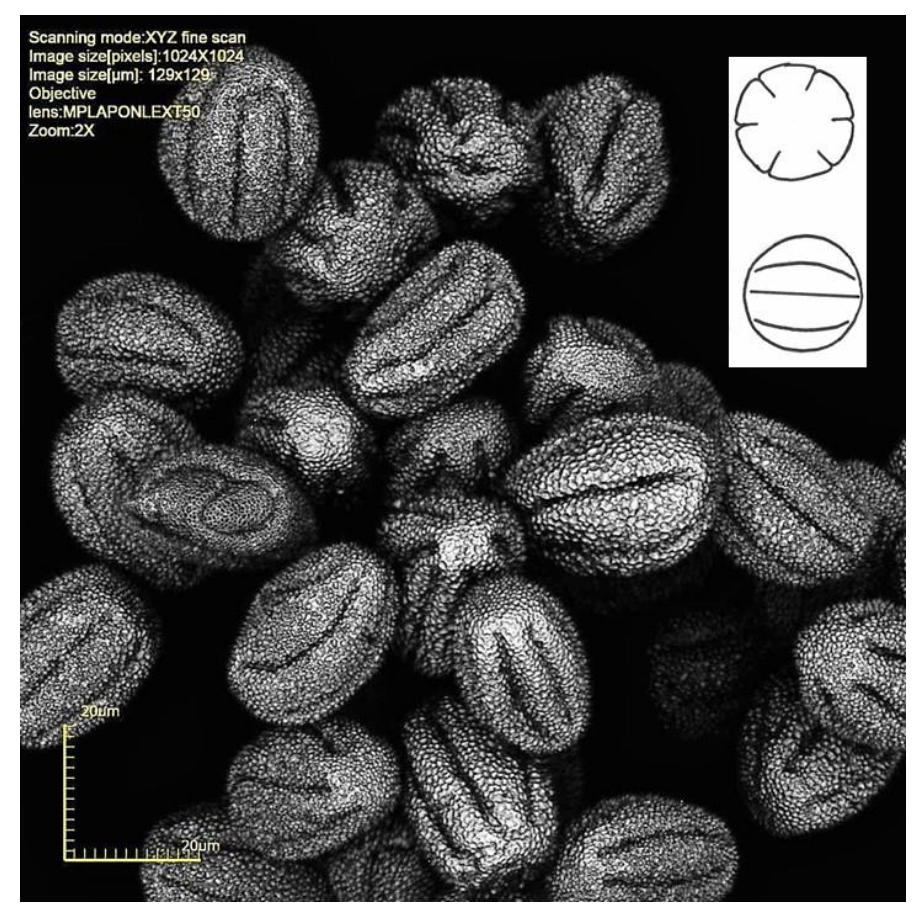

Figure 15: Stephanocolpatae. Pollen grains with four or more colpae. Sample species: Primula elatior. Type: Primula veris-Type. Original magnification x 2144 . 


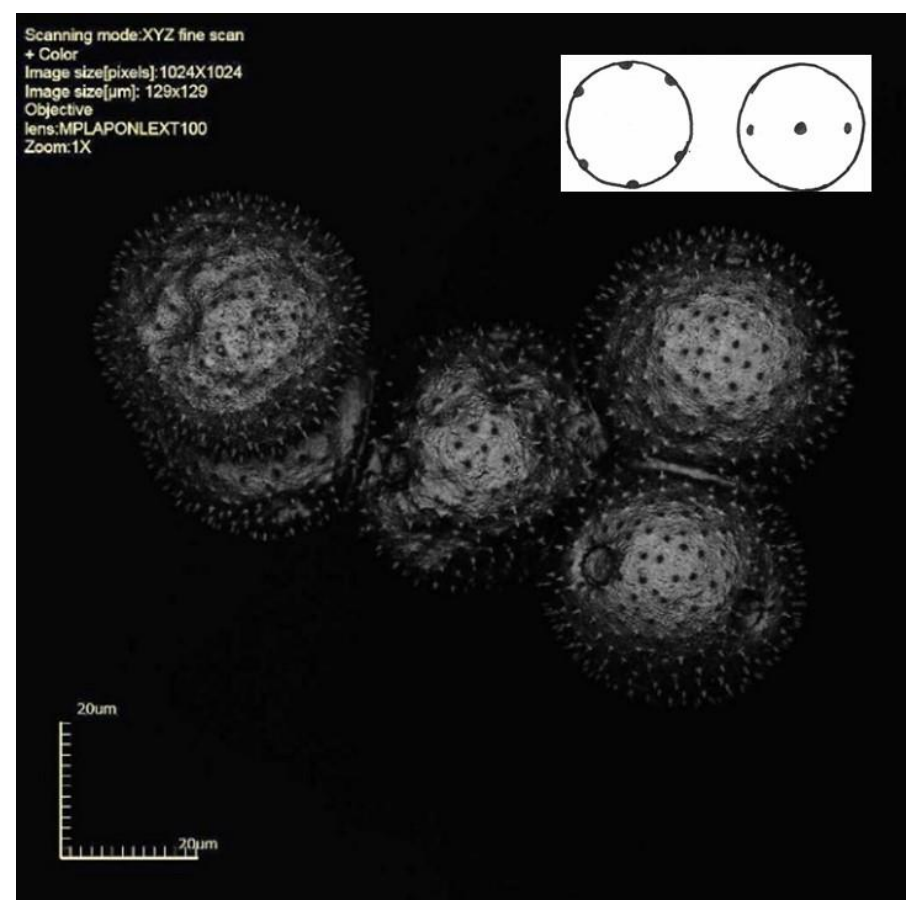

Figure 16: Stephanoporatae. Pollen grains with four or more equatorially distributed pores. Sample species: Campanula rapunculoides. Type: Campanula trachelium-Type. Original magnification x2136.

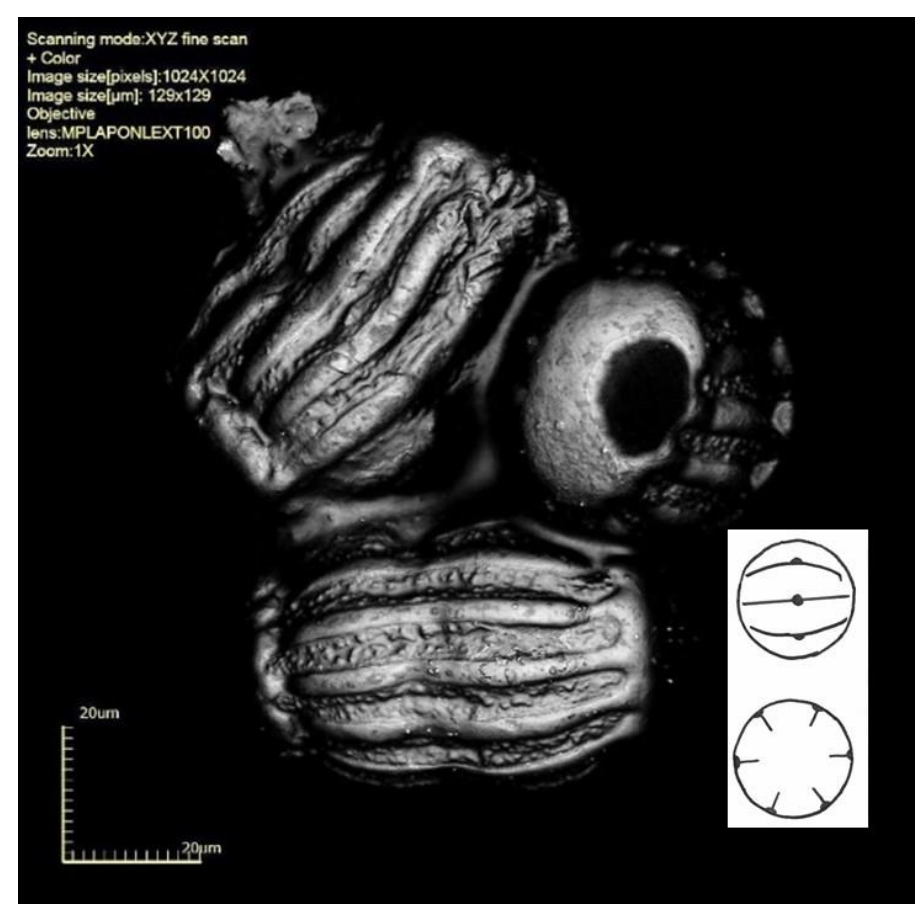

Figure 17: Stephanocolporatae. Pollen grains with four or more colpae, each colpus with an equatorial pore. Sample species: Polygala chamaebuxus. Type: Polygala chamaebuxus. Original magnification x2136. 


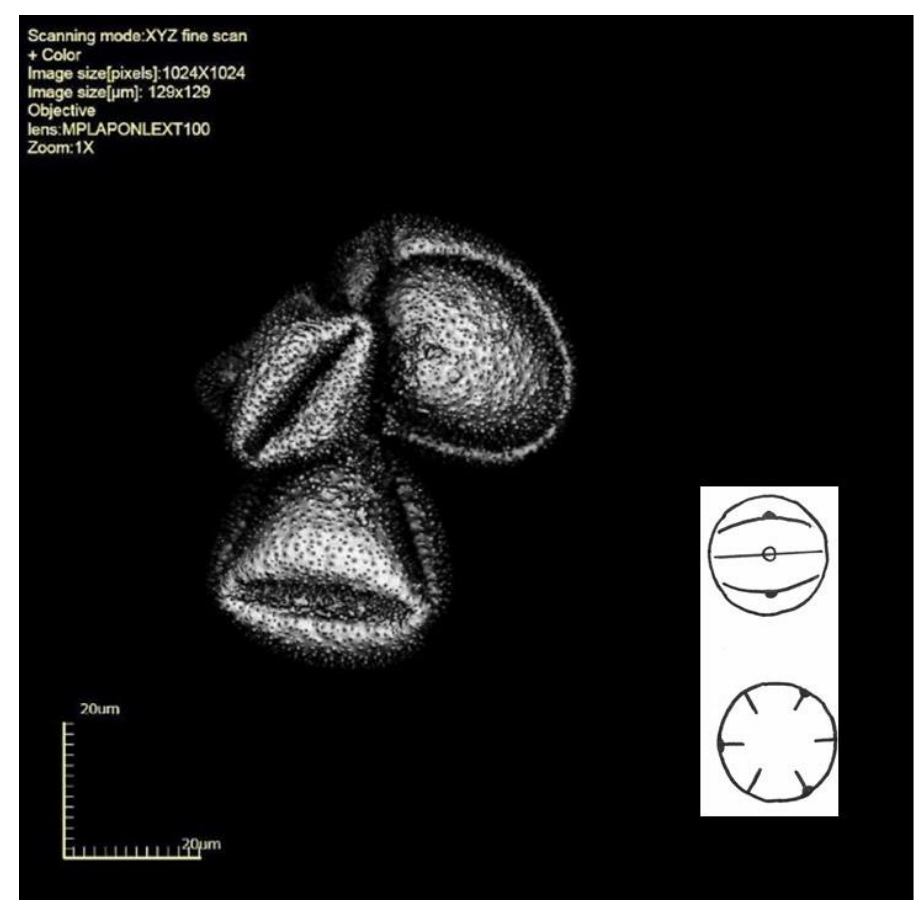

Figure 18: Heterocolpatae. Pollen grains with four or more colpae, only every second colpus with an equatorial pore. Sample species: Myosotis sylvatica. Type: Myosotis sylvatica. Original magnification $\mathrm{x} 2136$.

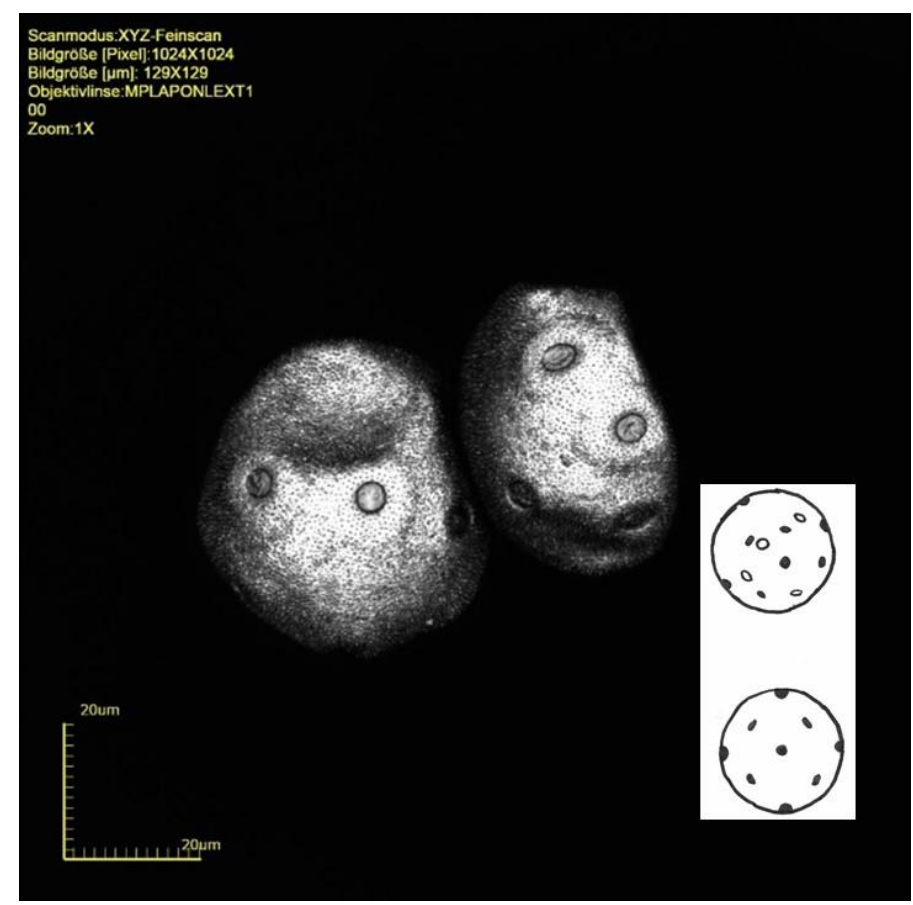

Figure 19: Periporatae. Pollen grains with four or more pores, distributed over the surface. Sample species: Berberis tungbergi. Type: Cerastium-Type. Original magnification x 2136 . 


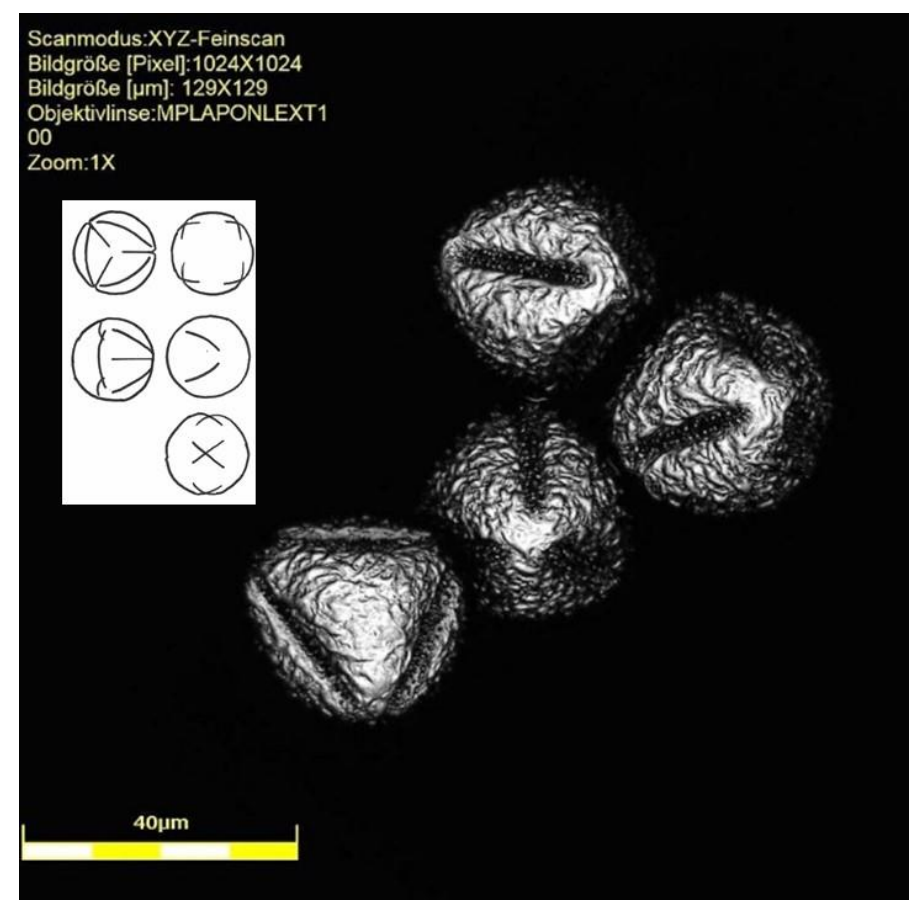

Figure 20: Pericolpatae. Pollen grains with four or more colpae, distributed over the surface. Sample species: Corydalis cava. Type: Corydalis cava-Type. Original magnification x 2136 .

Some species were not described or not listed in Beug (2004) [2]: Allium cepa, Anacamptis morio, Anthriscus sylvestris, Berberis tungbergi, Bergenia cordifolia, Brachypodium pinnatum, Cardamine pentaphyllum, Ficaria verna (Ranunculus ficaria), Juncus filiformis, Lamprocapnos spectabilis, Luzula pilosa, Magnolia grandiflora, Microthlapsi perfoliatum, Primula vulgaris-hybrid, Prunus armeniaca, Thymus pulegioides, Viola reichbachiana and Viola wittrockiana. The pollen of these species was classified based on visible morphological features.

For a few families (Asteraceae, Aquifoliaceae, Caprifoliaceae, Caryophyllaceae, and Geraniaceae), the pollen was classified in a group of classes composed of Tricolpatae, Tricolporoidatae and Tricolporatae, also as published by Beug (2004) [2].

The freshly prepared glass slides with pollen were evaluated with the Olympus LEXT OLS4000 $3 \mathrm{D}$ confocal laser scanning microscope at $1179 \mathrm{x}$ or $2350 \mathrm{x}$ magnification. Rarely, magnification up to $8545 \mathrm{x}$ was used to enhance pollen surface details (Figure 2). It took between 5-10 minutes to obtain a relevant picture, including seeking the most adequate pollen within the samples. The scanning time is dependent on the total depth of the sample. The surface morphology resolution was excellent and artifacts aside from mechanical trauma during collection and preparation were absent. Heating caused by the laser, which, for this application, is only at approximately $40{ }^{\circ} \mathrm{C}$, did not thermal damage the pollen structures, i.e. no shrinkage or drying artifacts were noted.

The quality of the pictures obtained by LSM was superior to that of non-sputtered samples evaluated by SEM. The latter were not suitable for evaluation. The sputtered samples evaluated by SEM were comparable in quality at similar relevant magnification. However, SEM on sputtered samples provides images with better resolution at higher magnification. For LSM, the maximal magnification reached with LEXT OLS4000 is $17280 x$. This high magnification is 
however irrelevant for pollen evaluation due to the loss of resolution (optical and digital magnification).

The classified pollen from all collected plants are presented in Table 2.

\section{$\underline{\text { Measurement of selected pollen types }}$}

Three related species were compared: Cardamine pentaphyllum, C. heptaphylla and $C$. pratensis (Figures 21-23). The following parameters were measured: width, height, length and angle of the pollen grains or the cavities which are determined by the reticulated structures on the surface. As an example, 25 values were collected per parameter. The average values are listed in Table 1.

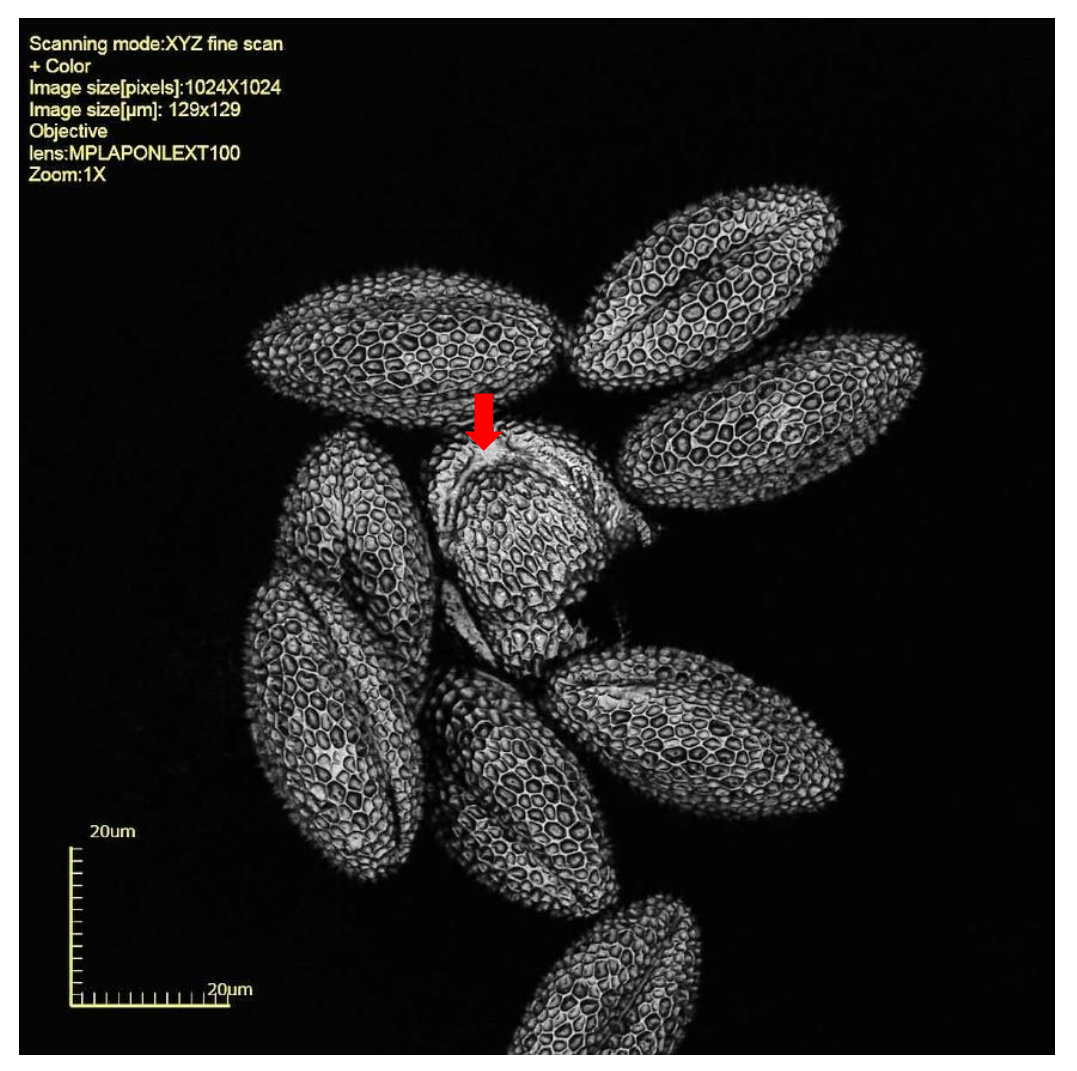

Figure 21: Cardamine pentaphyllum. One pollen grain is well positioned. The polar field can be seen (arrow). The pollen grains are similar to those of $C$. heptaphylla but are elongated in the longitudinal axis. LSM, Original magnification $\mathrm{x} 2136$. 


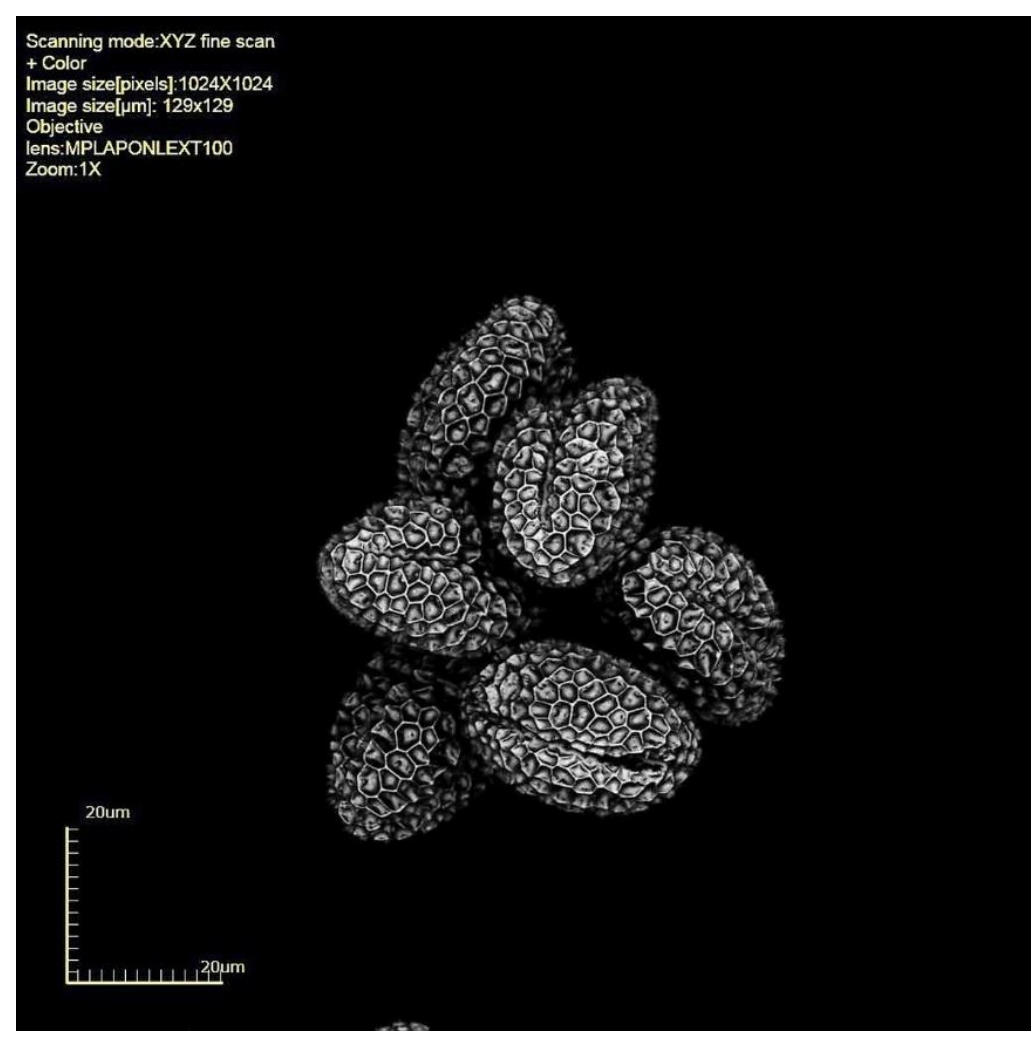

Figure 22: Cardamine heptaphylla. Depending on the position of the pollen grain, the colpi can be recognized. The surface is reticulated. Depending on the location of the pollen grain, the colpi can be recognized. The surface is reticulated. No pores can be seen. LSM, original magnification $\mathrm{x} 2136$.

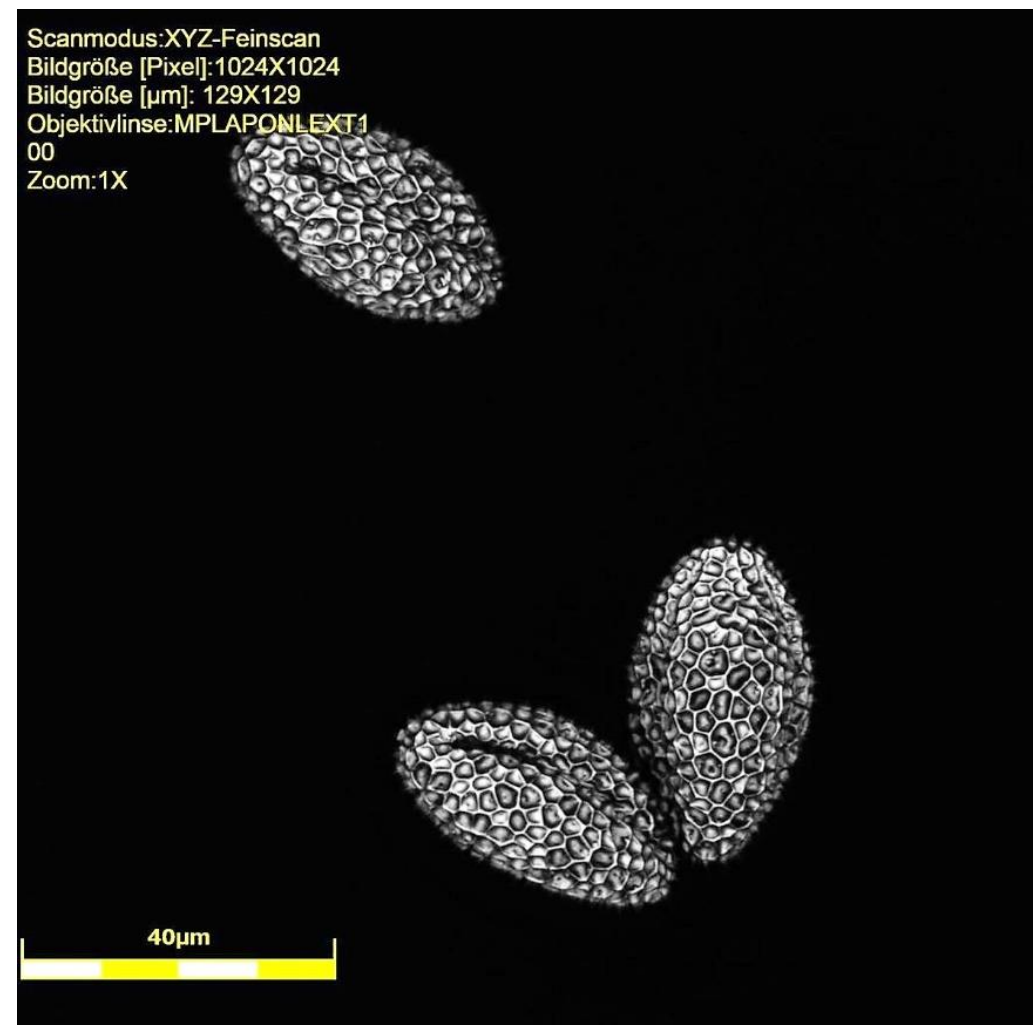

Figure 23: C. pratensis. Morphologically, there is no difference to the two types mentioned above, but especially in comparison to C. heptaphylla. LSM, original enlargement x 2136. 
Table 1: Dimensions of pollen grains and surface cavities in related species: Cardamine heptaphylla, $C$. pentaphyllum, $C$. pratensis (average values, $\mathrm{n}=25$; width, height, and length in $\mu \mathrm{m}$; angle in ${ }^{\circ}$ )

\begin{tabular}{lllllllll}
\multirow{2}{*}{ Species } & Pollen & \multicolumn{9}{c}{ Cavities } \\
\cline { 2 - 9 } & Width & Height & Length & Angle & Width & Height & Length & Angle \\
\hline C. heptaphylla & 32.4 & 7.1 & 33.1 & 12.3 & 2.2 & 0.2 & 2.2 & 4.4 \\
\hline C. pentaphyllum & 39.3 & 4.1 & 39.5 & 5.9 & 1.8 & 0.7 & 1.9 & 21.4 \\
\hline C. pratensis & 40.4 & 8.7 & 41.4 & 12.1 & 3.0 & 0.7 & 3.1 & 13
\end{tabular}

\section{Discussion}

$\underline{\text { Sampling of pollen and vegetation in the collection area }}$

In order to evaluate the possibility to classify plant pollen using a quick and cheap method (LSM) which provides details comparable to SEM, pollen from 168 species from 47 families and 129 genera was collected within 7 months (Table 2).

The collection area is located in the municipality of Oberbuchsiten in the canton of Solothurn, district of Gäu [21]. Any variation in pollen of the same species from other regions is not accounted for in the current paper. Such variations can play a role in different measurements, which is why the investigation area is briefly defined below.

The study area was limited to the Mühlebach creek and its inflows. The region is in the folds of the Jurassic mountains 480 to 740 meters above sea level and is dominated by limestone (calcareous soil). A summary of the geology of the area is available [22]. From top to bottom, there is an agricultural green meadow characterized by typical species (e.g. Tragopogon pratensis, Glebionis segetum, Leucanthemum vulgare, Elymus repens, Dactylis glomerate, etc.) followed by a mesophilic deciduous mixed forest on dry, alkaline soil with mainly Fagus sylvatica, Acer pseudoplatanus, Pinus sylvestris, and Picea specc., and with understocking mainly due to Crataegus laevigata, Lonicera xylosteum, and Ligustrum vulgare. In several places, the soil is moist and fresh, hence, different species of Carex appear as a moisture indicator. Furthermore, mainly willow trees (Salix specc.) represent a part of an alder/willow colline zone. The point where all other tributaries flow into the Mühlebach is the only location where Juncus filiformis grows. Just there, in the NNW direction (hill 'Alp'), at an altitude of 630 meters above sea level, is a slope covered by a semi-dry lawn with characteristic species including different orchid species (genus Orchis and Ophrys), as well as Polygala vulgaris. Towards the village of Oberbuchsiten, from an altitude of 595 meters above sea level, in the mixed forest, Buxus sempervirens is the most common undergrowth, mixed with shrubs like Hippocrepis emerus, Rosa canina et alpina, Lonicera xylosteum, Ligustrum vulgare, Cornus sanguinea, Corylus avellane, Daphne laureola, and Berberis vulgaris. In the herb layer, the plant communities are characterized by Petasites hybridus, Eupatorium cannabinum, Lysimachia vulgaris, and Solanum dulcamara, and different thistle (Carduoideae) and hawkweed (Hieracium) species. Common grass species include Brachypodium pinnatum, Anthoxanthum odoratum and different species of the genus Carex. 
Pollen grains differ in size and shape and can vary between 10 and $100 \mu \mathrm{m}$ in size. The largest pollen grains are found in pumpkin plants (Cucurbitacea), which are giants among pollen at 170-180 $\mu \mathrm{m}$ [23]. The pollen wall or sporoderm (the same is true for spores), is made up mainly of sporopollenin, the building material of the exine. Sporopollenin consists of carboxylic acids, especially p-cumaric acid (cinnamic acid) and long-chain, unbranched aliphatic and aliphatic polyhydroxy molecules. This composition makes sporopollenin chemically very resistant to acids, bases and solvents [1]. The sporoderm consists of two layers, the inner intine and the outer exine [1, 24]. The exine consists mainly of sporopollenin, which is present in approximately $6 \mathrm{~nm}$ large granules. The exine includes the inner endexine and the outer ectexine. There are fundamental anatomical differences between naked and covered semen (Gymnospermae and Angiospermae). In Gymnospermae, the endexine is lamellar. The ectexine has an inner foot layer and an outer compact layer, as well as a granular or alveolar layer in between. In Angiospermae, the endexine has a granular structure. The endexine and the dense basal layer of the ectexine together form the nexine. The rest of the ectexine forms the sexine which can be highly structured. Intectate pollen grains have a sexine consisting of chopsticks, clubs, cones, and warts without an outer layer (tectum). Tectate pollen grains have a layer on the outer side, which forms the tectum (roof) through columns (Columellae, Baculae). The tectum can be designed differently, i.e. perforated, multi-layered, etc. The resulting surface structures are important for the differentiation of the pollen. Various substances are embedded in the cavities of the tectum, namely pollen cement and incompatibility proteins [1]. Only the more resistant outer part of the pollen wall, the exine, has a chance of being preserved or even fossilized if it is embedded in the sediment under reducing conditions.

The intine is tender and usually consists of two to three layers. The outermost layer contains a high proportion of pectin (polyuronide), i.e. vegetable polysaccharides which easily detach from the exine (sliding / separating layer). The inner layers of a pollen grain mainly consist of cellulose fibers. When a pollen grain germinates, the vegetative cell grows around the intine to the pollen tube (Figure 1).

There are important differences in the individual pollen grains (regardless of whether they are mono-, di-, tetra- or poly-grained), which accompany the different surface structures. The surface may show different patterns, e.g. psilat, clavat, scabrat, echinat, verrucat, rugut, reticulat, baculat, foveolat, gemmat, striat or frustillat [24]. These structures are visible in SEM, LSM and light microscopy, and are helpful in determining the original plant or group of plants.

\section{$\underline{\text { Definition of pollen classes }}$}

Pollen classes and classifications can refer to: pollen units (e.g. polyads, tetrads), pollen shape (e.g. saccate, polygonal), the type and location of the aperture (e.g. inaperturatae, colpatae), or the surface pattern (e.g. scabrat, reticulat ) [2, 18].

There are different nomenclatures, which are probably due to historical reasons [18]. In order to organize and simplify the historically broad range of terms, various systems have been introduced, e.g. the '-treme system' to describe the configuration of the aperture (-treme from trema as a synonym for aperture), or the NPC classification. The NPC classification is also based on the Aperturae: $\mathrm{N}$ for number, $\mathrm{P}$ for position, and $\mathrm{C}$ for character.

The present work is based on the classification published by Beug (2004) [2], who studied 2500 plant species for Central Europe and neighboring areas and revealed 586 identifiable pollen types (33 main classes with different types). The system presented is easy to use and relates to the number of pollen grains, i.e. Polydaea (many pollen grains are united in one structure), Tetradeae (consisting of four pollen grains), Dyadeae (consisting of two pollen grains); the presence of air sacs (Vesiculatae); the absence of pores (Inaperturatae) or colpae but the 
presence of longitudinal ribs or branched/non-branched pseudocolpae (Polyplicatae); the presence of fenestrations in the ectexine (Fenestratae); the presence of pores and/or colpae and the number (singular, double, triple) of these structures (Monoporatae, -colpatae, Dicolpate, porate, -colporate, Triporatae, -colpatae, -colporatae); differently shaped or interconnected colpae, i.e. ring-shaped or helical colpae, or 2 to 3 polar fused colpae, or colpae that divide the surface of the pollen grain into square areas and are connected to one another (Syncolpatae); four or more pores or colpae (Stephanoporate, -colpatae); combination of four or more pores or colpae (Stephanocolporatae, Heterocolpatae); or on the surface statistically distributed pores or colpae (Periporatae, -colpate, -colporatae) [2].

The further classification into types within the pollen classes is not within the scope of this work. It would be wrong, however, to believe that a specific pollen morphology can be assigned to a single species as mentioned elsewhere [25]. On the contrary, pollen can be attributed to one single species only in rare cases. The determination of fossil and recent pollen leads in most cases only to taxonomic units, i.e. several species, one or more genera, one family or part of a family or parts of several families. Therefore, the name of the pollen type is designated according to either a species, genus or family [2], i.e. pollen is named as follows:

- species, if the species is unique: e.g. Plantago lanceolatum,

- for plant family, a group name is applied: e.g. Rosacea indiff. that is for family Rosacea but not further differentiated,

- for plant genus, a group name is applied: e.g. Stellaria indiff. that is for the genus Stellaria but not further differentiated,

- there are also type designations for fossil types or fossil types with recent species (Knox, 1984).

\section{Comparison of the LSM and SEM methods}

Although pollen is routinely evaluated by light microscope [2, 12] and the techniques used allow the inner structures of pollen grains to be visualized, electron microscopy, especially SEM, has contributed significantly to the classification of pollen. '.. The terminology applied to the pollen wall is daunting, especially as it has been developed from early light microscopy work, and then transposed to the images seen in the transmission and scanning electron microscopes...' [18]. Furthermore, '...The introduction of SEM in palynology in the mid of the 1960s was a key innovation in the study of the fine relief (sculpture) of pollen and spore surfaces. Advantages of SEM include the relatively simple and rapid preparation methods and the supreme depth of focus. SEM was considered, from the very first moment, as the quantum leap in EM...' [18]. The first SEM images of pollen were published in 1965 [17].

LSM (Olympus LEXT OLS4000 3D confocal laser scanning microscope) is a technique which uses a focused laser and confocal technology for scanning an object. 3D confocal laser scanning microscopy allows surfaces to be studied and imaged at high resolution with a total magnification up to 17280x. Although this technology was not developed for the evaluation of cells and tissues, LSM application has been described previously on sperm cells [19] but it has never been used to classify pollen. The technique is simple to apply, no freeze drying and/or sputtering is needed. Both technologies are limited by the wavelength of light but the possible total magnification of LSM is beyond the limits of light microscopy. This raises the question of whether pollen can be clearly identified by LSM. In addition, it was questionable whether the heating generated by the laser leads to artifacts. Instead, the use of LSM proved to be efficient, easy to use and poor in artifacts. 
Fresh pollen samples were evaluated at magnifications of 1179x or 2350x. Occasionally, magnifications up to $8545 \mathrm{x}$ were used for a more detailed evaluation. At the magnification applied, surface morphology resolution was excellent and free of artifacts induced by heating or drying. Comparable enlargements did not result in significantly better resolutions by SEM as opposed to LSM. Nonetheless, the magnifications possible with SEM cannot be achieved using LSM. In addition, using magnifications above 8545x, the images from SEM on sputtered pollen showed better resolution of the surface structure compared to results achieved with LSM. In contrast, without sputtering, the image quality achieved by SEM is very poor, and the results are unusable for pollen evaluation.

Related species belonging to different pollen classes and types can be clearly differentiated using LSM, e.g. Viola reichbachiana and V. arvensis (Figure 24). It emerged that Viola reichbachiana pollen is tricolpate whereas $V$. wittrockiana pollen is stephanocolpate. Neither species was described by Beug (2004) [2], but they were easy to identify with LSM. This was also true for 16 other species that were not listed in Beug (2004) [2]. Hence morphological determination of the pollen class was simple by LSM. This is supported by the fact that in several cases, species from the same genus revealed a different pollen class, e.g. Berberis tungbergi (Periporatae) vs. B. vulgaris (Syncolpatae) or Sanguisorba minor (Tricolpatae) vs. S. officinalis (Stephanocolporatae).
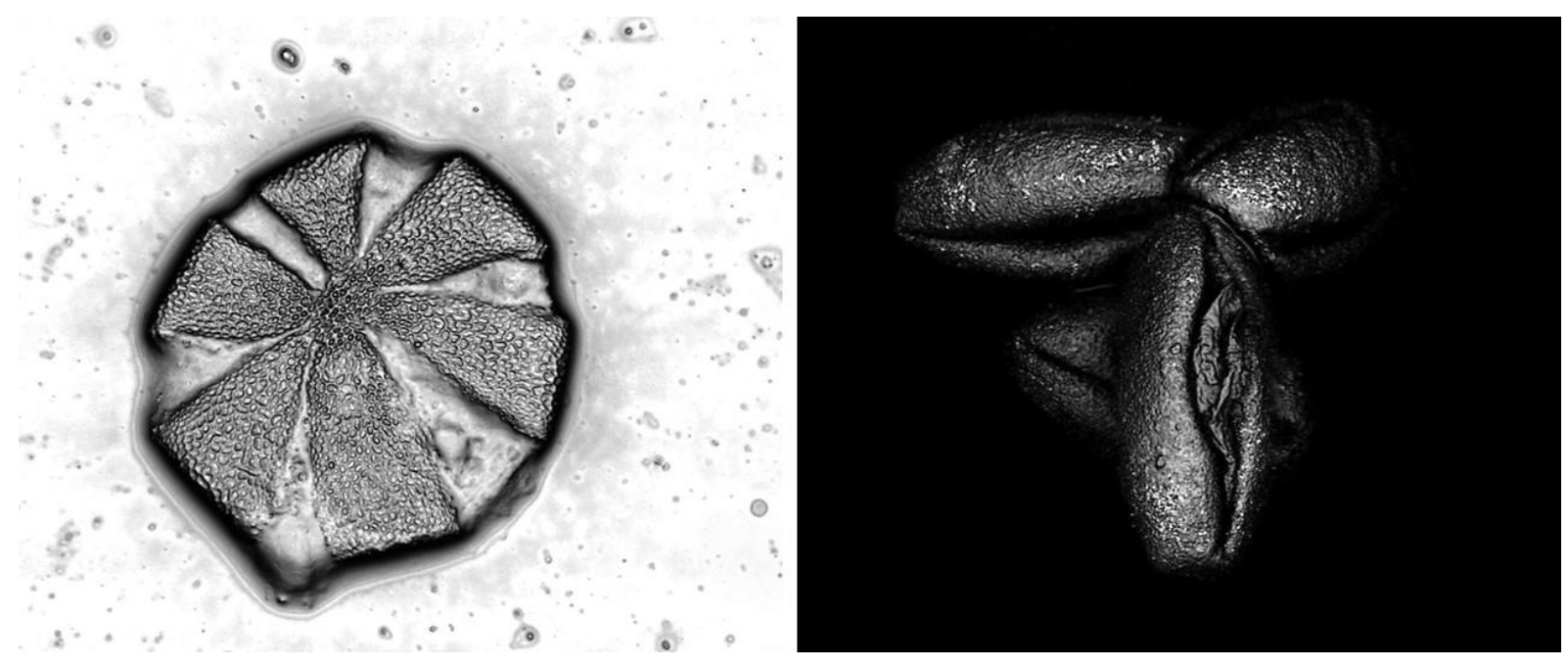

Figure 24: Left: Viola arvensis (Stephanocolporatae). LSM, Original enlargement x2136. Right: Viola reichbachiana (Tricolpatae). LSM, original enlargement x2136.

A great advantage of using the LEXT OLS4000 is the integrated software that allows numerous types of geometrical measurements and, in case of the pollen, a simple approach for taking measurements that are deemed to be relevant. An example for potential application is the possible species-specific differences in pollen from Brassicaceae. In many cases, the pollens of related species or genera are so similar that they are not only grouped together in one class, but even in one type. This means that the species cannot be distinguished, e.g. in the Brassicaceae type, where it is assumed that the sizes play a role [2]. To identify or confirm differences between similar species, three related species, Cardamine hepatphylla, $C$. pentaphyllum and $C$. pratensis, were examined using LSM. The pollen of these three species belongs to the Tricolpatae class (type: Brassicaceae), whereby $C$. pentaphyllum is a species not described by Beug (2004) [2] but was morphologically classified within the scope of the present study. The pollen of all three species has a reticulate surface and bears three colpae but pores can be recognized. Therefore, all three species have a tricolpate pollen. The Brassicaceae with 
174 Central European species from 56 genera have a small polar field on the mostly thickwalled pollen grains [2]. Because of the large number of species, it is questioned whether the species can be distinguished as there are only minor morphological differences. Considering the three aforementioned species, the pollen grains of $C$. pentaphyllum, are, for instance, more elongated in the longitudinal axis than the pollen grains of $C$. heptaphylla. The measurement of the pollen resulted in significantly different values for the dimensions of the pollen grains and the cavities on the surface, i.e. the pollen of these species differs at least in their dimensions. Although this statement applies to only a few specimens in a narrowly defined area, it is conceivable that, with sufficient material, several types of the Brassicaceae might be clearly distinguished.

And finally, color-setting is applicable to improve the visibility of details in LSM images (Figure 1).

\section{$\underline{\text { Conclusion }}$}

The approach of LSM using the Olympus LEXT OLS4000 3D confocal laser scanning microscope for the palynological examination of pollen was tested for the first time.

Overall, LSM was shown to be efficient and easy to use. After preparing the pollen, a 3D scan takes 5-10 minutes, including localization of suitable pollen grains to scan. The pollen does not have to be processed (sputtered) as would be necessary for obtaining a clear SEM image. The 3D scans can be measured quickly and easily with the LEXT software. Artifacts were not observed. At the same magnification, the image quality from LSM is comparable to that from SEM on a sputtered sample. Overall, the display of pollen by LSM is much less time-consuming and more cost effective than with the SEM method.

\section{Acknowledgement}

This work was carried out as part of a Matura thesis at the high school of the Feusi Bildungszentrum in Bern, Switzerland. The authors would like to thank the thesis supervisor, Dr. Ute Hamann for her constant support. Prof. Dr. med. vet. Michael Stoffel from the Institute of Veterinary Anatomy at the University of Bern, Switzerland thankfully provided support by SEM. We would like to thank Dr. Gp Cribaro and Anne Koski from Protext SCP (www.protext.xyz) in Barcelona, Spain, for proofreading the article.

\section{Author Contributions}

The authors contributed as follows. Conceptualization, determination of species, sampling of pollen: A.-L.W. and K.W.; visualization and data sampling by LSM: A.-L.W., K.W., S.P., M.S., L.L., N.W.; original draft preparation and writing: A.-L.W., K.W., N.W.

\section{Conflict of Interest}

There is no conflict of interest. There was no funding.

\section{References}


1. Sitte, P.; Ziegler, H.; Ehrendorfer, F.; Bresninsky, A. Strasburger- Lehrbuch der Botanik für Hochschulen, 33rd ed.; Gustav Fischer: Stuttgart, Germany, 1991; 702-704.

2. Beug, H.-J. Leitfaden der Pollenbestimmung für Mitteleuropa und angrenzende Gebiete, 1st ed.; Verlag Dr. Friedrich Pfeil: München, Germany, 2004.

3. Fazal, H.; Ahmad, N.: Haider Abbasi, B. Identification, characterization, and palynology of high-valued medicinal plants. Sci World J 2013, 2013: 283484.

4. Bryant, V.M.; Hall, S.A. Archaeological Palynology in the United States: A Critique. Am Antiq 1993, 58, 277-286.

5. Scott, A.C. An introduction to the applications of palaeobotany and palynology to coal geology. Bull Soc Geol France 1991, 162, 145-153.

6. Straka, H. Pollenanalyse und Vegetationsgeschichte, 2nd ed.; A. Ziemsen: Wittenberg, Germany, 1970: 7.

7. Bryant Jr., V.M.; Jones, J.G.; Mildenhall, D.C. Forensic palynology in the United States of America. J Palynology 1990, 14, 193-208.

8. Horrocks, M.; Walsh, K.A.J. Fine Resolution of Pollen Patterns in Limited Space: Differentiating a Crime Scene and Alibi Scene Seven Meters Apart. J Forensic Sci 1999, 44, 417-420.

9. Bobiș, O.; Mărghitaș, L.A.; Dezmirean, D.S.; Bărnuțiu, L.I.; Mărgăoan, R.; Bonta, V. The importance of melissopalynology in addition to physico-chemical analysis on botanical authenticity testing of monofloral honey. Bulletin of University of Agricultural Sciences and Veterinary Medicine Cluj-Napoca. Animal Science and Biotechnologies 2013, 70, 24-31.

10. Soares, S.; Amaral, J.S.; Oliveira, M.B.P.P.; Mafra, I. A. Comprehensive Review on the Main Honey Authentication Issues: Production and Origin. Compr Rev Food Sci Food Saf 2017, 16, 1072-1100.

11. Mercuri, A.M. Applied palynology as a trans-disciplinary science: the contribution of aerobiology data to forensic and palaeoenvironmental issues. Aerobiologia 2015, 31, 323339.

12. Riding, J.B.; Kyffin-Hughes, J.E. A review of the laboratory preparation of palynomorphs with a description of an effective non-acid technique. Rev Brasil Paleontologia 2004, 7, 13-44.

13. von der Ohe, W.; Persano Oddo L.; Plana, M.L.; Morlot, M.; Martin, P. Harmonized methods of melissopalynology. Apidologie 2004, 35 (Suppl. 1), S18-S25.

14. Guggenheim, R. Rasterelektronenmikroskopische und morphometrische Untersuchungen an Tilia-Pollen: Ein Beitrag zur Artunterscheidung von Tilia platyphyllos SCOP. und Tilia cordata Mill. in der Palynologie. (Scanning Electron Microscopic and Morphometric Studies of Tilia Pollen: a Contribution to Species Differentiation of Tilia platyphyllos SCOP. and Tilia cordata Mill in Palynology). Flora 1975, 164, 287-338.

15. Jones, G.D.; Bryant Jr., V.M. A comparison of pollen counts: Light versus scanning electron microscopy. Grana 2007, 46, 20-33.

16. Tatzreiter, S. Präparation von Pollen und Sporen für das Rasterelektronenmikroskop und Lichtmikroskop unter Verwendung von Rhodaniden. Grana 1985, 24, 33-43.

17. Thornhill, J.W.; Matta, R.K.; Wood, W.H. Examining three-dimensional microstructures with the scanning electron microscope. Grana Palynol. 1965, 6, 3-6.

18. Halbritter, H.; Ulrich, S.; Grímsson, F.; Weber, M.; Zetter, R.; Hesse, M.; Bucher, R.; Svojtka, M.; Frosch-Radivo, A. Illustrated Pollen Terminology, 2nd ed. Springer: open, Springer International Publishing AG, Cham, Switzerland. https://link.springer.com/content/pdf/10.1007\%2F978-3-319-71365-6.pdf Accessed online via swissbib (08.09.2019). 
19. Dustmann, J.; von der Ohe, K. Scanning electron microscopic studies on pollen from honey. IV. Surface pattern of pollen of Sapium sebiferum and Euphorbia spp (Euphorbiaceae). Apidologie 1993, 24, 56-66.

20. Weber, K.; Waletzky, A.; Fendl, D.; Ordóñez, P.; Takawale, P.; Hein, F.; Riedel, W.; König, A.; Kunze, M.; Leoni, A-L.; Rivera, J.; Quirici, R.; Romano, I.; Paepke, S.; Okazaki, Y.; Hardisty, J.F. New Method for Sperm Evaluation by 3-Dimensional Laser Scanning Microscopy in Different Laboratory Animal Species. Int J Toxicol 2014, 33, 353-361.

21. Gemeindeverwaltung Oberbuchsiten. (http://www.oberbuchsiten.ch/de/portrait/). (accessed 27.08.2019).

22. Bitterli, T.; Jordi, H.A.; Gerber, M.E.; Gnägi, C.; Graf, H.R. Blatt 1108 Murgenthal. Geol.Atlas Schweiz 1:25000, Erläut.113. Open access. 2011.

https://files.be.ch/bve/agi/geoportal/geo/lpi/GEOAT25/113_1108_Murgenthal_ERL.pdf (accessed 09.09.2019)

23. Schütt, P.; Schuck, H.J.; Stimm, B. Lexikon der Baum- und Straucharten. Das Standardwerk der Forstbotanik. Morphologie, Pathologie, Ökologie und Systematik wichtiger Baum- und Straucharten, 2nd ed; Verlag Nikol, Hamburg, Germany. 2002 (reprint from 1992); 390.

24. Kaltenrieder, P.; von Ballmoos, P. Introduction to Pollen Analysis. 2003. http://www.botany.unibe.ch/paleo/pollen_e/index.htm (accessed 08.09.2019)

25. Wikipedia. Pollen, https://de.wikipedia.org/wiki/Pollen, (accessed 07.09.2019). 
Table 2: Alphabetical list of families of sampled and evaluated species and pollen classes according to Beug (2004) and distribution of species into pollen classes.

Species printed in bold and with '*' are described as 'non-viti' or were not mentioned in Beug (2004). For some families, Tricolpatae, Tricolporoidatae and Tricolporatae were summarized as described by Beug (2005).

\begin{tabular}{|c|c|c|}
\hline Family & | Pollen class & Species \\
\hline \multirow[t]{2}{*}{ Adoxaceae } & Tricolporoidatae & Sambucus nigra \\
\hline & Tricolporatae & Viburnum lantana \\
\hline Alismataceae & Periporatae & Alisma plantago-aquatica \\
\hline Amaryllidaceae & Monocolpatae & $\begin{array}{l}\text { Allium cepa*, A. ursinum, Leucojum vernum, } \\
\text { Narcissus pseudonarcissus }\end{array}$ \\
\hline Apiaceae & Tricolporatae & $\begin{array}{l}\text { Aegopodium podagraria, Anthriscus sylvestris*, } \\
\text { Daucus carota*, Heracleum sphondylium*, Laser } \\
\text { trilobum }\end{array}$ \\
\hline Apocynaceae & Tricolpatae & Vinca minor \\
\hline Asparagaceae & Monocolpatae & $\begin{array}{l}\text { Anthericum ramosum, Convallaria majalis, } \\
\text { Muscari neglectum }\end{array}$ \\
\hline \multirow[t]{2}{*}{ Asteraceae } & $\begin{array}{l}\text { Tricolpatae, } \\
\text { Tricolporoidatae } \\
\text { Tricolporatae }\end{array}$ & $\begin{array}{l}\text { Achillea millefolium, Cirsium oleraceum, C. } \\
\text { palustre, C. tuberosum, Bellis perennis, } \\
\text { Buphthalmum salicifolium, Erigeron annuus, } \\
\text { Leucanthemum vulgare, Eupatorium cannabinum, } \\
\text { Glebionis segetum (Chrysanthemum segetum), } \\
\text { Petasites albus, P.hybridus, Tanacetum vulgare, } \\
\text { Tussilago farfara }\end{array}$ \\
\hline & Fenestratae & $\begin{array}{l}\text { Cichorium intybus, Crepis biennis, } C \text {. tectorum, } \\
\text { Hieracium murorum, } H \text {. pilosella, } \\
\text { Taraxacum sect. Ruderalia, Tragopogon pratensis }\end{array}$ \\
\hline Aquifoliaceae & \begin{tabular}{|l|} 
Tricolpatae, \\
Tricolporoidatae \\
Tricolporatae \\
\end{tabular} & Ilex aquifolium \\
\hline \multirow[t]{2}{*}{ Berberidaceae } & Periporatae & Berberis tungbergi* \\
\hline & Syncolpatae & Berberis vulgaris \\
\hline Betulacea & Triporatae & Betula pendula \\
\hline \multirow[t]{2}{*}{ Boraginaceae } & Heterocolpatae & Myosotis sylvatica \\
\hline & Stephanocolporatae & Pulmonaria officinalis \\
\hline \multirow[t]{2}{*}{ Brassicaceae } & Tricolpatae & $\begin{array}{l}\text { Alliaria petiolata, Capsella bursa-pastoris, } \\
\text { Cardamine heptaphylla, C. pentaphyllum } *, C . \\
\text { pratensis }\end{array}$ \\
\hline & Tricolporatae & Microthlaspi perfoliatum* \\
\hline Buxaceae & Periporatae & Buxus sempervirens \\
\hline Campanulaceae & Stephanoporatae & Campanula rapunculoides, Phyteuma spicatum \\
\hline \multirow[b]{2}{*}{ Caprifoliaceae } & Triporatae & Knautia arvensis, $K$. dipsacifolia \\
\hline & \begin{tabular}{|l|} 
Tricolpatae, \\
Tricolporoidatae \\
und Tricolporatae \\
\end{tabular} & Valeriana officinalis \\
\hline Caryophyllaceae & Periporatae & Cerastium arvense, Silene dioica \\
\hline
\end{tabular}




\begin{tabular}{|c|c|c|}
\hline & \begin{tabular}{|l} 
Tricolpatae, \\
Tricolporoidatae \\
Tricolporatae \\
\end{tabular} & Lonicera caprifolium \\
\hline Cistaceae & Tricolporatae & Helianthemum nummularium \\
\hline Convulaceae & Periporatae & Calystegia sepium \\
\hline Cyperaceae & Periporatae & $\begin{array}{l}\text { Carex caryophyllea, C. flacca, C. pendula, } C . \\
\text { sylvatica }\end{array}$ \\
\hline Euphorbiaceae & Tricolporoidatae & Euphorbia helioscopia \\
\hline \multirow[t]{2}{*}{ Fabaceae } & Tricolporatae & $\begin{array}{l}\text { Anthyllis vulneraria, Hippocrepis comosa, } H . \\
\text { emerus, Lathyrus sylvestris, } L . \text { vernus, Lotus } \\
\text { corniculatus, Ononis spinosa, Trifolium pratense, } \\
\text { T. resupinatum, Vicia cracca }\end{array}$ \\
\hline & Tricolpatae & Onobrychis viciifolia \\
\hline Fagaceae & Tricolporatae & Fagus sylvatica \\
\hline Geraniaceae & $\begin{array}{l}\text { Tricolpatae, } \\
\text { Tricolporoidatae } \\
\text { Tricolporatae }\end{array}$ & $\begin{array}{l}\text { Geranium pratense, } G \text {. pyrenaicum, } G . \\
\text { robertianum }\end{array}$ \\
\hline Grossulariaceae & Periporatae & Ribes uva-crispa \\
\hline Hypericaceae & Tricolporoidatae & Hypericum hirsutum, H. perforatum \\
\hline Juncaceae & Tetradeae & Juncus filiformis ${ }^{*}$, Luzula pilosa* \\
\hline \multirow[t]{2}{*}{ Lamiaceae } & Tricolpatae & $\begin{array}{l}\text { Ajuga genevensis, A.reptans, Betonica officinalis, } \\
\text { Lamium album, L. galeobdolon, L. hybridum, } \\
\text { Melampyrum sylvaticum, Melittis melissophyllum, } \\
\text { Stachys sylvatica }\end{array}$ \\
\hline & Stephanocolpatae & $\begin{array}{l}\text { Mentha spicata, Rosmarinus officinalis, Salvia } \\
\text { pratensis, Thymus pulegioides* }\end{array}$ \\
\hline Magnoliaceae & Monocolpatae & Magnolia grandiflora* \\
\hline Menyanthaceae & Tricolporoidatae & Menyanthes trifoliata \\
\hline Oleaceae & Tricolpatae & Ligustrum vulgare \\
\hline Onagraceae & Triporatae & Circaea lutetiana \\
\hline Orchidaceae & Poyladeae & $\begin{array}{l}\text { Anacamptis morio*, Ophrys apifera, Orchis } \\
\text { militaris }\end{array}$ \\
\hline \multirow{2}{*}{ Papaveraceae } & Tricolpatae & Chelidonium majus, Lamprocapnos spectabilis* \\
\hline & Pericolpatae & Corydalis cava \\
\hline Pinaceae & Vesiculatae & Pinus sylvestris \\
\hline \multirow[t]{2}{*}{ Plantaginaceae } & Tricolporoidatae & Digitalis lutea \\
\hline & Periporatae & Plantago lanceolata, P. media \\
\hline Poaceae & Monoporatae & $\begin{array}{l}\text { Brachypodium pinnatum } * \text {, Bromus erectus, } \\
\text { Dactylis glomerata, Elymus repens, Lolium } \\
\text { perenne, Melica nutans, Phleum pratense }\end{array}$ \\
\hline Polygalaceae & Stephanocolporatae & Polygala chamaebuxus, $P$. vulgaris \\
\hline Polygonaceae & Tricolporatae & Rumex acetosa \\
\hline \multirow{2}{*}{ Primulaceae } & Tricolporatae & Lysimachia vulgaris \\
\hline & Stephanocolpatae & Primula elatior, $P$. veris, $\boldsymbol{P}$. vulgaris-Hybride* \\
\hline Ranunculaceae & Tricolpatae & $\begin{array}{l}\text { Anemone nemorosa, A. ranunculoides, Aquilegia } \\
\text { vulgaris, Caltha palustris, Clematis vitalba, } \\
\text { Ficaria verna (Ranunculus ficaria)*, Helleborus } \\
\text { foetidus, Ranunculus acris }\end{array}$ \\
\hline
\end{tabular}




\begin{tabular}{|c|c|c|}
\hline \multirow[t]{3}{*}{ Rosaceae } & Tricolporoidatae & $\begin{array}{l}\text { Crataegus laevigata, C. monogyna, Cydonia } \\
\text { oblonga, Fragaria moschata, F. vesca, Malum } \\
\text { communis, Mespilus germánica, Potentilla aurea, } \\
\text { Prunus armeniaca*, P. avium, P. cerasus, } P \text {. } \\
\text { domestica, P. laurocerasus, P. padus, P. spinosa, } \\
\text { Pyrus communis, Rosa canina, Rubus sectio, } \\
\text { Sorbus aucuparia }\end{array}$ \\
\hline & Tricolpatae & Sanguisorba minor \\
\hline & Stephanocolporatae & Sanguisorba officinalis \\
\hline Rubiaceae & Stephanocolpatae & Galium album, G. odoratum, G. verum \\
\hline \multirow[t]{2}{*}{ Sapindaceae } & Tricolpatae & Acer pseudoplatanus \\
\hline & Tricolporatae & Aesculus hippocastanum \\
\hline \multirow[t]{2}{*}{ Saxifragaceae } & Tricolpatae & Bergenia cordifolia* \\
\hline & Tricolporoidatae & Chrysosplenium alternifolium \\
\hline Solanaceae & Tricolporatae & Solanum dulcamara \\
\hline Urticaeae & Triporatae & Urtica dioica \\
\hline \multirow[t]{2}{*}{ Violaceae } & Tricolpatae & $\begin{array}{l}\text { Viola canina, V. reichenbachiana* Viola } \\
\text { wittrockiana* }\end{array}$ \\
\hline & Stephanocolpatae & Viola arvensis \\
\hline
\end{tabular}

